\title{
Review \\ Hypoxia-Induced Non-Coding RNAs Controlling Cell Viability in Cancer
}

\author{
Maria Magdalena Barreca ${ }^{1} \mathbb{D}$, Chiara Zichittella ${ }^{1}$, Riccardo Alessandro ${ }^{1,2} \mathbb{D}$ and Alice Conigliaro ${ }^{1, * \mathbb{D}}$ \\ 1 Department of Biomedicine, Neuroscience and Advanced Diagnostics (Bi.N.D.), Section of Biology and \\ Genetics, University of Palermo, 90133 Palermo, Italy; mariamagdalena.barreca@unipa.it (M.M.B.); \\ chiara.zichittella@unipa.it (C.Z.); riccardo.alessandro@unipa.it (R.A.) \\ 2 Institute for Biomedical Research and Innovation (IRIB), National Research Council (CNR), \\ 90146 Palermo, Italy \\ * Correspondence: alice.conigliaro@unipa.it
}

Citation: Barreca, M.M.; Zichittella,

C.; Alessandro, R.; Conigliaro, A.

Hypoxia-Induced Non-Coding RNAs Controlling Cell Viability in Cancer. Int. J. Mol. Sci. 2021, 22, 1857. https://doi.org/10.3390/ijms22041857

Academic Editor:

Anne-Catherine Prats

Received: 22 December 2020

Accepted: 10 February 2021

Published: 12 February 2021

Publisher's Note: MDPI stays neutral with regard to jurisdictional claims in published maps and institutional affiliations.

Copyright: () 2021 by the authors. Licensee MDPI, Basel, Switzerland. This article is an open access article distributed under the terms and conditions of the Creative Commons Attribution (CC BY) license (https:// creativecommons.org/licenses/by/ $4.0 /)$.

\begin{abstract}
Hypoxia, a characteristic of the tumour microenvironment, plays a crucial role in cancer progression and therapeutic response. The hypoxia-inducible factors (HIF- $1 \alpha, \mathrm{HIF}-2 \alpha$, and HIF-3 $\alpha$ ), are the master regulators in response to low oxygen partial pressure, modulating hypoxic gene expression and signalling transduction pathways. HIFs' activation is sufficient to change the cell phenotype at multiple levels, by modulating several biological activities from metabolism to the cell cycle and providing the cell with new characteristics that make it more aggressive. In the past few decades, growing numbers of studies have revealed the importance of non-coding RNAs (ncRNAs) as molecular mediators in the establishment of hypoxic response, playing important roles in regulating hypoxic gene expression at the transcriptional, post-transcriptional, translational, and posttranslational levels. Here, we review recent findings on the different roles of hypoxia-induced ncRNAs in cancer focusing on the data that revealed their involvement in tumour growth.
\end{abstract}

Keywords: hypoxia; HIF; lncRNAs; miRNAs; cancer; proliferation; cell cycle

\section{Introduction}

\subsection{Hypoxia in Solid Tumours}

Due to excessive proliferation and abnormal blood vessel formation, most solid tumours are irregularly vascularized and display local regions of hypoxia: reduction of oxygen partial pressure $\left(\mathrm{pO}_{2}\right)$; in these regions will grow clusters of cells with more aggressive phenotypes, high resistance to therapy, and able to affect the surrounding microenvironments [1-3]. To survive in hypoxic conditions, tumour cells activate multiple molecular and cellular mechanisms, including alteration in metabolic pathways, alteration in ion channel activity and changes in gene expression through transcriptional and post-transcriptional mechanisms. These biological responses are designed as the hypoxic adaptive responses which activation depends on the function of Hypoxia Hypoxia-Inducible Factors (HIFs).

The transcription factor HIF is a heterodimer consisting of an oxygen-regulated $\alpha$ subunit (HIF- $1 \alpha$ or HIF- $2 \alpha$ ) and a constitutive $\beta$ subunit, also known as the aryl hydrocarbon receptor nuclear translocator (ARNT), which presents the bHLH domain required for DNA binding, two PAS domains (PAS-A and PAS-B) essential for dimerization, and one transactivation domain [4]. Among the isoforms, HIF-1 $\alpha$ is ubiquitously expressed in various cells and it is considered as the major regulator of oxygen homeostasis, it governs the acute adaptation to hypoxia, whereas HIF- $2 \alpha$ expression begins during chronic hypoxia. Both HIF- $1 \alpha$ and HIF- $2 \alpha$ function as central transcriptional mediators of hypoxic responses, even if with a different pattern [5]; while the role of HIF-3 under hypoxia as well as its mode of action are less clear. Several studies suggested that HIF- $3 \alpha$ might be functionally distinct. Specifically, in many studies, it was showed that the HIF- $3 \alpha$, also known as inhibitory PAS domain protein (IPAS), inhibits HIF-1 and HIF-2 expression and/or activity 
in cell culture [6-8] while recent data showed that HIF- $3 \alpha$ variants can form $\alpha \beta$ dimers that, binding its target genes via the canonical HRE, possess transactivation activity [9].

The reduction of $\mathrm{pO}_{2}$ is the key event that switches the hypoxic responses inducing HIF- $\alpha$ activity. At low oxygen levels, HIF- $\alpha$ avoids proteasome degradation and migrates to the nucleus where dimerizes with HIF-1 $\beta$ forming the HIF complex (for a more comprehensive reading on the nuclear transport see [10]). This complex, together with the transcriptional coactivators, will induce genes expression after binding the conserved cis-regulatory site $\left(5^{\prime}(\mathrm{A} / \mathrm{G}) \mathrm{CGTG}-3^{\prime}\right)$ called Hypoxia Responsive Elements (HREs), on the promoters of hypoxia-regulated genes.

HIF-induced transcriptional regulation changes the cellular phenotype by acting simultaneously on multiple pathways. HIF activity affects cell growth, cell metabolism, redox homeostasis, inflammation, angiogenesis, cell cycle progression, and chemoresistance thus boosting the onset and progression of cancers [11-14].

Interestingly, in the last years, the literature highlights an increasing number of noncoding RNAs that, induced directly or indirectly by HIF complex, cooperate with it, in establishing the hypoxic responses.

Here we collected and review the recent discoveries about the role of hypoxia-induced non-coding RNAs in tumour growth, focusing on hypoxia-induced long non-coding RNAs (lncRNAs), and micro RNAs (miRNAs) Figure 1.

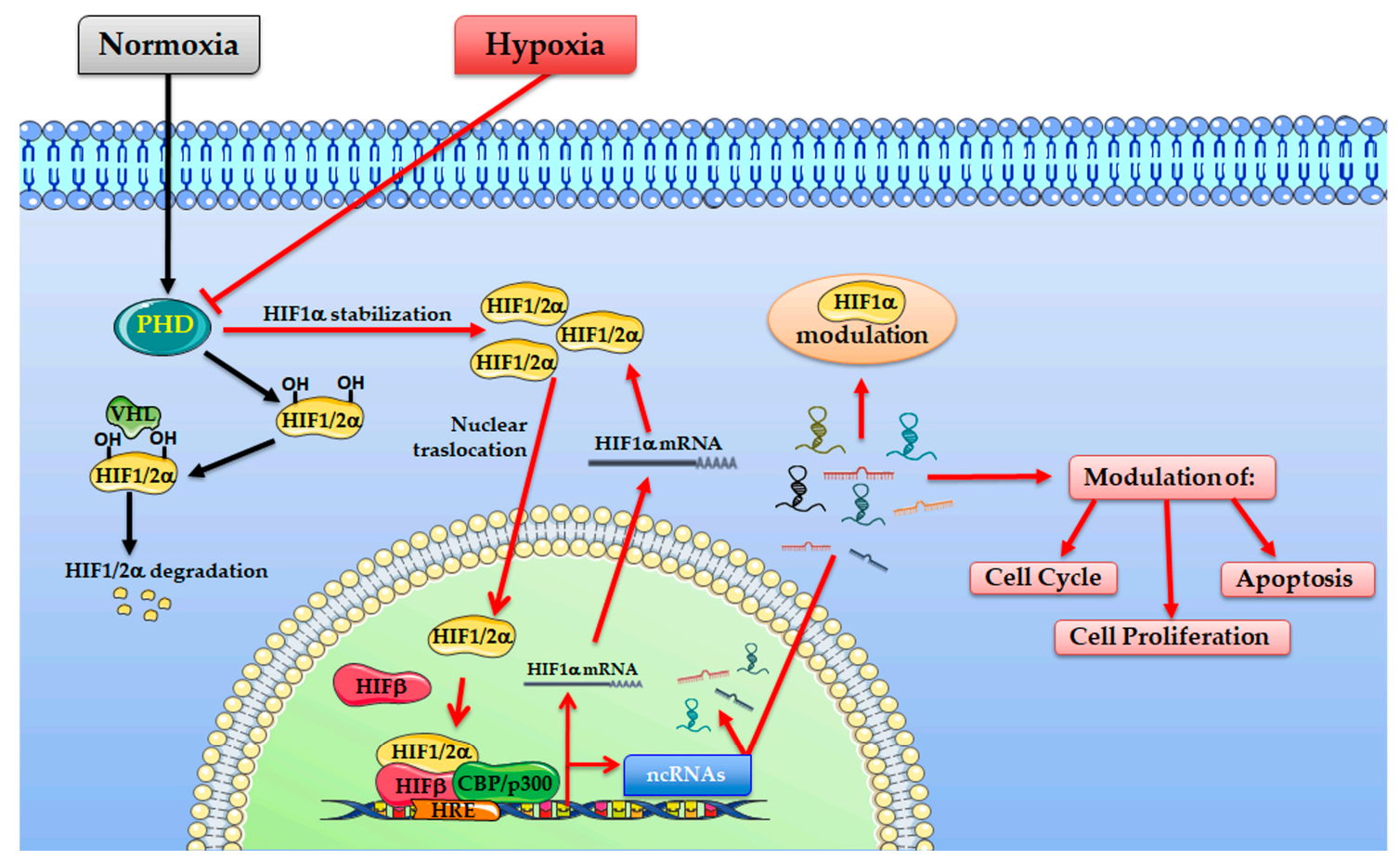

Figure 1. Hypoxia-inducible factor (HIF) complex transcriptionally activates non-coding RNAs (ncRNAs) in response to hypoxia. Under normoxia (black arrows), HIF-1/2 $\alpha$ subunits are subjected to hydroxylation by prolyl hydroxylase domain enzymes (PHDs) and other prolyl hydroxylases. Hydroxylated HIF-1/2 $\alpha$ subunits are recognized by VHL proteins and targeted for subsequent ubiquitination and proteasomal degradation. Under hypoxia (red arrows), low $\mathrm{pO}_{2}$ results in HIF-1/2 $\alpha$ accumulation, nuclear translocation and dimerization with HIF-b, finally, after recruitment of CBP/p300, the transcription initiation complex binds the promoter of target genes inducing their expression. Among the hypoxia-induced RNAs, the ncRNAs (miRNAs or lncRNAs) will be involved in different pathways, regulating cell proliferation, cell cycle and cell death. Moreover, some of these can regulate HIF itself.

\subsection{Non-Coding RNAs}

It is well known that $98 \%$ of the human transcriptome encode for different classes of the non-coding RNAs (ncRNAs). According to their size, the ncRNAs are generically classified into small non-coding RNAs ( $<200$ nucleotides, such as miRNA, small nuclear/nucleolar 
RNA, piwi-interacting RNAs and transfer-RNAs) and lncRNAs ( $>200$ nucleotides). In addition to these two main categories of non-coding RNAs, there is the family of circRNA that differs from the other for functions and structure, characterized by their circular configuration through the $5^{\prime}$ to $3^{\prime}$-phosphodiester bond.

MiRNAs are a class of single-stranded, endogenous small non-coding RNAs containing about 20-25 nucleotides, synthesized from larger RNA transcripts by a complex enzymatic pathway. MiRNAs are transcribed as pri-miRNAs by RNA polymerase II or III, or processed from non-coding RNAs, or from the introns of protein-coding genes (miRtrons) [15]. Pri-miRNAs are then cleaved by the microprocessor complex, formed by the nuclear RNase III enzyme DROSHA and the DGCR8, into a stem-loop structure of 70-110 nucleotides, known as a precursor miRNA (pre-miRNA) [16]. The pre-miRNAs transported to the cytoplasm will be cleaved by the RNase III enzyme/DICER/TRBP2 to generate a 22-nucleotide mature double-stranded miRNA duplex. This miRNA duplex includes the two-strand pair miR-3p/miR-5p, each of which may be selected as functional and recruited by the ARGONAUTE proteins associated with the RNA-induced silencing complex. Single strand miRNAs mainly regulate gene expression at the post-transcriptional level, leading to mRNA degradation or translational repression through partial complementarity to their targets. However, some miRNAs have been found also in the nucleus where they control gene expression at the transcriptional level [17-19]. This picture is further complicated by the discovery of RNA modifications that occur in controlling miRNA biogenesis and functions [20].

Long non-coding RNAs (lncRNAs) are a class of RNA transcripts larger than 200 nucleotides in length with no protein-coding capacity [21]. Based on their genomic contexts lncRNAs can be classified into five categories: (I) promoter-associated lncRNAs, (II) enhancer-associated lncRNAs, (III) natural antisense transcripts, (IV) gene bodyassociated (sense) lncRNAs and (V) long intergenic ncRNAs [22]. LncRNAs genes are very similar to protein-coding genes, presenting marks at their promoters or enhancers, these are transcribed by RNA polymerase II, spliced at canonical splicing sites, and often polyadenylated $[23,24]$. Several studies have demonstrated that lncRNAs play critical roles in regulating gene expression at multiple levels, including epigenetic (i.e., the $\mathrm{X}$ chromosome silencing, genomic imprinting, and chromatin modification), transcriptional (transcription activation or inactivation), and post-transcriptional level (splicing, mRNA turnover, translation, and RNA interference), through interaction with other biomolecules, such as proteins, regulatory DNA regions, and miRNAs [25,26]. Moreover, the property of each lncRNAs changes according to localization. Nuclear lncRNAs modulate gene expression in cis or in trans, by interacting with transcriptional co-regulators and chromatin remodelling complexes, or impeding transcription factor binding [27]; moreover, by interacting with RNA binding proteins, may control RNA splicing, like for MALAT and NEAT [28]. Into the cytoplasm, lncRNAs bind to various protein partners thus regulating RNA stability, degradation, and translation, moreover they may act as sponges for microRNA thus restoring mRNA targets as demonstrated in several cancer models [29,30].

CircRNAs are mainly formed by "back-splicing" of precursor mRNA (pre-mRNA) and are enriched in the cytoplasm and exosomes [31,32]. These ncRNAs are characterized by a special form with a covalent loop instead of the most common linear which renders them resistant to degradation by RNase R and therefore more stable than linear RNA [33]. According to the source of the genome and biogenesis patterns, circRNAs are divided into four categories: ecircRNAs, ciRNAs, EIciRNA, tricRNAs. The most studied are the circRNAs derived from exons called "ecircRNA"; these are mainly distributed into the cytoplasm, where work as a sponge for miRNAs, allow protein-protein interaction, or in some cases can be translated through a cap-independent mechanism [34-36].

Having a look to the other circRNA: EIciRNAs are formed of both exonic and intronic sequences of coding genes [37], "ciRNAs" are circular intronic RNAs, mainly enriched in the nucleus where they are involved in gene regulation [38]. Finally, a special class of intronic circular RNA, "tricRNA" is generated during pre-tRNA splicing [39]. 
Regardless of their origin, circRNAs have been found to be involved in both physiological and pathological processes through different mechanisms. In the cytoplasm circRNAs are implicated in RNA regulation, or miRNA regulation by acting as competing endogenous RNA [40]; moreover, circRNAs may interact with proteins acting as bridges for protein-protein interaction. In the nucleus, these control gene expressions have been found to be involved in several physiological and pathological process [41-43].

\section{The Hypoxia-Induced Non-Coding RNAs}

Hypoxia-responsive ncRNAs have been found to play important roles in hypoxiadriven cancer progression modulating the hypoxic gene expression at transcriptional, and post-transcriptional levels, by acting as effectors of HIF or as direct modulators of the HIF-transcriptional cascade [44,45] (Figure 1).

Profiling techniques and bioinformatics analysis allowed us to unveil more and more hypoxia-regulated non-coding RNA by the presence of the hypoxia response elements (HREs) in their promoter regions [46]. Moreover, several studies have described hypoxic induction of non-coding RNAs lacking HREs indicating an indirect regulation often involving epigenetic mechanisms; HIF may control non-coding RNAs expression through histone deacetylase activation, or affecting miRNA maturation machinery $[47,48]$.

Using microarray analysis on hypoxia-induced gastric cancer cell lines, Wang et al. identified several hypoxia-responsive IncRNAs in gastric cancer. In particular, they found that an intronic antisense lncRNA named lncRNA-AK058003 was among the most induced lncRNAs upon hypoxia treatment in all examined gastric cancer cell lines [49], data confirmed also in breast cancer [50]. In addition, recent data demonstrated that HIF- $1 \alpha$ can directly regulate circRNAs at the transcriptional level $[51,52]$ and that HIF-induced circRNAs may promote cancer growth as demonstrated in bladder [53]; however, unlike miRNAs and lncRNAs, the mechanisms of HIF-mediated circRNAs expression have been less investigated and will not be further addressed in this review.

Considering the different mechanisms through which ncRNAs might control tumour growth, these have been divided here into two different groups: (1) the hypoxia-induced ncRNAs that work as HIF effector in promoting cell growth or inhibiting cell death, and (2) the Hypoxia induce ncRNAs such as aHIF-1 $\alpha$, linc-ROR, and lincRNA-p21 which directly or indirectly regulate the HIFs proteins (Figure 2).

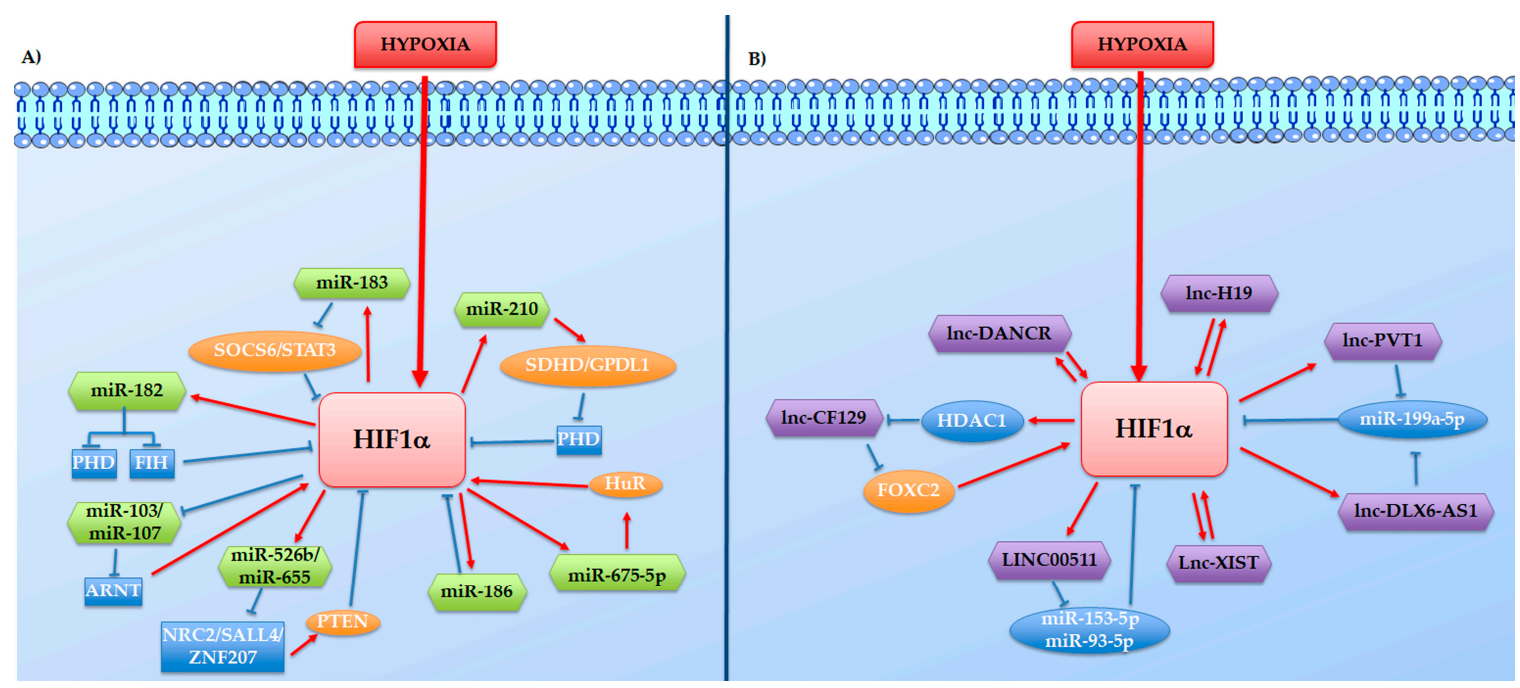

Figure 2. Direct or indirect feedback loops between HIF-1 $\alpha$ and hypoxia-regulated ncRNAs. The hypoxia-regulated ncRNAs, HIF-1 $\alpha$, and other co-operators intertwine to form reciprocal feedback loops in both positive and negative manners, represented in the figure respectively with red arrows and blue lines. (A) Reciprocal feedback loops between HIF- $1 \alpha$ and hypoxia-regulated lncRNAs. (B) Reciprocal feedback loops between HIF-1 $\alpha$ and hypoxia-regulated miRNAs. 


\subsection{The Hypoxia-Induced ncRNAs as HIF's Effectors in Controlling Cell Viability}

2.1.1. Hypoxia-Induced miRNAs with a Role in Tumour Growth

Hypoxic microenvironment can promote tumour growth in a dual mode: by inducing cell cycle deregulation and by allowing apoptosis escape. Several ncRNAs may act as molecular mediators through which, HIF complex controls these processes. Here we collected the most recent and relevant finding of hypoxia-induced miRNAs (hypoxiamiR), further summarized in Table 1.

Table 1. List of hypoxia-responsive miRNAs involved in cell proliferation, apoptosis and cell cycle regulation.

\begin{tabular}{|c|c|c|c|c|c|}
\hline miRNAs & Cancer Types & $\begin{array}{c}\text { Regulation } \\
\text { Hypoxia-Mediated }\end{array}$ & Targets & Functions & References \\
\hline \multirow{8}{*}{$\mathrm{miR}-210$} & Schwannoma cells & upregulation & NA & $\begin{array}{l}\text { enhances tumour cell } \\
\text { proliferation }\end{array}$ & {$[54]$} \\
\hline & neuroblastoma cells & upregulation & Bcl-2 & induces apoptosis & [55] \\
\hline & $\begin{array}{l}\text { Breast and melanoma } \\
\text { cancer cells, }\end{array}$ & upregulation & $\begin{array}{c}\text { Max's Next Tango } \\
(\mathrm{MNT})\end{array}$ & $\begin{array}{l}\text { inhibits hypoxia-induced } \\
\text { cell cycle arrest }\end{array}$ & {$[56]$} \\
\hline & Glioma stem cells & upregulation & $\begin{array}{l}\text { MNT-Max } \\
\text { complex }\end{array}$ & $\begin{array}{l}\text { inhibits hypoxia-induced } \\
\text { cell cycle arrest }\end{array}$ & [57] \\
\hline & $\begin{array}{l}\text { Epithelial ovarian } \\
\text { cancer }\end{array}$ & upregulation & PTPN1 & $\begin{array}{l}\text { promotes cell proliferation } \\
\text { and inhibits apoptosis }\end{array}$ & {$[58]$} \\
\hline & Epatoma cells & upregulation & AIFM3 & $\begin{array}{l}\text { inhibits hypoxia-induced } \\
\text { cell cycle arrest }\end{array}$ & [59] \\
\hline & Glioma cells & upregulation & SIN3A & $\begin{array}{l}\text { inhibits proliferation and } \\
\text { promotes apoptosis }\end{array}$ & {$[60]$} \\
\hline & $\begin{array}{l}\text { triple-negative breast } \\
\text { cancer }\end{array}$ & upregulation & p53 & promotes cell proliferation & {$[61]$} \\
\hline miR-210-3p & bladder cancer & upregulation & NA & induces apoptosis & {$[62]$} \\
\hline miR-145 & breast cancer & upregulation & TGFb2, HuR & promotes proliferation & [63] \\
\hline \multirow[b]{2}{*}{ miR-191 } & $\begin{array}{l}\text { non-small cell lung } \\
\text { cancer cells }\end{array}$ & upregulation & NF1A & promotes proliferation & {$[64]$} \\
\hline & gastric cancer & upregulation & $\begin{array}{l}\text { MDR1/P-gp, LRP } \\
\text { and Bcl-2 } \\
\text { pathways }\end{array}$ & promotes proliferation & {$[65]$} \\
\hline miR-27a & gastric cancer & upregulation & PTEN & promotes proliferation & {$[66]$} \\
\hline miR-382 & breast cancer & upregulation & PDCD4 & inhibits apoptosis & [67] \\
\hline $\mathrm{miR}-424$ & colorectal cancer & upregulation & DAPK, KLF4 & $\begin{array}{c}\text { promotes } \\
\text { hyperproliferation and } \\
\text { decreases apoptosis }\end{array}$ & [68] \\
\hline miR-103/107 & pancreatic cancer cells & upregulation & NA & $\begin{array}{l}\text { promotes proliferation } \\
\text { and inhibits apoptosis }\end{array}$ & [69] \\
\hline \multirow[t]{2}{*}{$\operatorname{miR}-21$} & cervical cancer cells & upregulation & $\begin{array}{l}\text { PTEN/AKT } \\
\text { pathway }\end{array}$ & promotes cell growth & {$[70]$} \\
\hline & gastric cancer & upregulation & RASSF8 & promotes cell growth & [71] \\
\hline $\mathrm{miR}-224$ & bladder cancer cells & downregulation & FGFR3 & upregulates proliferation & [72] \\
\hline $\operatorname{miR}-100$ & pancreatic cancer cells & downregulation & Vimentin & inhibits proliferation & [73] \\
\hline miR-548an & $\begin{array}{l}\text { acute myeloid } \\
\text { leukaemia cells }\end{array}$ & downregulation & p21, STAT3 & inhibits cell growth & {$[74]$} \\
\hline miR-101 & glioblastoma & upregulation & NA & promotes cell proliferation & {$[75,76]$} \\
\hline
\end{tabular}


Table 1. Cont.

\begin{tabular}{cccccc}
\hline miRNAs & Cancer Types & $\begin{array}{c}\text { Regulation } \\
\text { Hypoxia-Mediated }\end{array}$ & Targets & Functions & References \\
\hline miR-675 & colorectal cancer cells & upregulation & $\begin{array}{c}\beta \text {-catenin } \\
\text { localization }\end{array}$ & regulates cell cycle & [77,78] \\
\cline { 2 - 5 } & $\begin{array}{c}\text { non-small cell lung } \\
\text { cancer }\end{array}$ & upregulation & p53 & promotes cell proliferation & {$[79]$} \\
\cline { 2 - 5 } miR-421 & $\begin{array}{c}\text { gastric cancer } \\
\text { carcinoma }\end{array}$ & upregulation & Caspase 3 & inhibits apoptosis \\
\hline miR-204 & $\begin{array}{c}\text { hepatocellular } \\
\text { carcinoma }\end{array}$ & downregulation & TWIST1 & $\begin{array}{c}\text { induces tumour cell } \\
\text { proliferation }\end{array}$ \\
\hline miR-33a & $\begin{array}{c}\text { hepatocellular } \\
\text { carcinoma }\end{array}$ & downregulation & NA & $\begin{array}{c}\text { upregulates tumour cell } \\
\text { proliferation }\end{array}$ \\
\hline
\end{tabular}

The most studied hypoxiamiR is the miR-210, it is regulated by HIF in various cell types through the direct binding of the transcription factor to the HREs on its promoter. It was found to represses genes expressed under normoxia, and required to promote tumour growth [84]. The upregulation of miR-210 in solid tumours was associated with bad prognosis, indicating that the target genes affected by miR-210 have a functional impact on tumour malignancy and drug resistance [85-87]. Several studies, to date, have demonstrated its involvement in various kinds of tumours affecting a large number of cellular functions, including mitochondrial metabolism, angiogenesis, DNA repair, and cell survival. Wang et al. showed that, in schwannoma cells, hypoxia-induced miR210 promotes autophagy activation, tumour cell proliferation and angiogenesis, while inhibits apoptosis; intriguingly, in this study, the authors noted that miR-210 promoter region, containing the HREs, was hypermethylated in normoxia, while demethylated in hypoxia thus suggesting a double control on miR-210 expression [54]. Concerning the molecular mediators, firstly, the Grandori group identified in breast and melanoma cancer cells that hypoxia-induced miR-210 targets the Max's Next Tango (MNT) mRNA, a key transcriptional repressor of the MYC-MAX network. MNT downregulation allows c-MYC to push cells through the cell cycle [56]. Similar results were obtained by Yang and colleagues in glioma stem cells, in which they observed that hypoxia upregulated miR-210 avoided G0/G1 cell cycle arrest via MNT-Max complex-dependent transcription repression [57]. In an in vitro model of ovarian cancer, Li et al. demonstrated that hypoxia upregulates miR-210 thus promoting tumour cell proliferation and cell clone generation via targeting PTPN1 (tyrosine-protein phosphatase non-receptor type 1) and inhibiting apoptosis [58]. It is notable that several studies highlighted the predicted miR-210 seed sites in apoptosis-related mRNA transcripts such as AIFM3 (Apoptosis-Inducing Factor Mitochondrion-associated 3), CASP8AP2 (Caspase-8-Associated Protein-2) and SIN3A (a transcription repressor that forms a complex with histone deacetylase 1) $[59,60,88,89]$.

Recently, an interesting manuscript of Du et al. demonstrated that hypoxia-induced miR-210-3p controls cell proliferation by promoting Warburg effects and, concomitantly by inhibiting p53 activity in triple-negative breast cancer [61].

Taken together, these studies support a model in which, through the regulation of a single miRNA, HIF can simultaneously target multiple factors with a key role in the apoptotic process, ultimately promoting uncontrolled cell proliferation and carcinogenesis.

Another highly expressed hypoxiamir, regulated by both HIF- $1 \alpha$ and HIF- $2 \alpha$, is miR21. It is considered to act as oncomirs by targeting many tumour suppressor genes involved in cell proliferation, apoptosis, and invasion in several types of cancer [69,70]. The prooncogenic role of miR-21 was in deep studied in the last years since to propose anti-miR-21 as a strategy to fight tumour growth [90]; here is interesting to note that hypoxia-induced miR-21 shows an elevated level in hypoxic exosomes. Li et al., demonstrated that tumour- 
derived exosomes enriched in miR-21 are internalized by normoxic cells driving recipient cells toward a pro-metastatic phenotype [91].

One of the miRNAs, which expression increases in the hypoxic tumour, is the miR675. It was found up-regulated by HIF in several tumours including Glioblastoma $[75,76]$ and colorectal cancer [77]. Recently it was described its role in controlling cell cycle by regulating Glycogen Synthase Kinase $3 \beta$ (GSK-3 $\beta$ ) activity and allowing $\beta$-catenin nuclear localization [78]. MiR-675 was found up-regulated in hypoxic non-small cell lung cancer where in addition to promoting cell proliferation, it acts on apoptosis by directly inhibiting the expression of p53 [79]; also in this case, through the induction of a single miRNA, HIF promotes tumour growth by acting simultaneously on several molecular pathways.

In a study conducted by Zhao et al., miR-191 was found to be upregulated by HIF- $1 \alpha$. They showed that miR-191 promoted the proliferation and migration of non-small cell lung cancer cells (NSCLC) by targeting of NF1A (Nuclear factor 1 A-type) under chronic hypoxic conditions [64]. In breast cancer, Nagpal and colleagues showed that miR-191 is upregulated by both HIF- $1 \alpha$ and HIF- $2 \alpha$ and its overexpression is responsible for cancer aggressiveness by promoting cell proliferation, and survival under hypoxia; moreover, they demonstrated that miR-191 promotes TGF $\beta$ expression thus revealing a molecular link between HIF and TGF $\beta$ signalling pathways, both pivotal in the regulation of breast cancer metastasis [63].

He et al. highlighted the role of HIF- $1 \alpha$ in transcriptional upregulation of the miR-224 in gastric cancer cells. Through target gene validation, these authors revealed that miR-224 directly targets RASFF8 (Ras association domain family member 8), stimulating p65 nuclear translocation and NF-kB transcriptional activity to confer gastric cancer cells with more aggressive phenotype [71]. Their results suggest that hypoxia-inducible miR-224 promotes gastric cancer cell growth by downregulating RASSF8 and acts as an oncogene, implying that inhibition of miR-224 may have potential as a therapeutic target for patients with hypoxic gastric tumours [71].

Several studies conducted on gastric cancer cells using different approaches (i.e., ChIP assay, luciferase assay, as well as qRT-PCR) revealed the direct relationship between HIF- $1 \alpha$ and different miRNAs. Ge et al. observed that miR-421, up-regulated by HIF- $1 \alpha$, can promote tumour behaviour in gastric cancer by targeting the caspase- 3 thus inhibiting apoptosis [80]. Zhao and colleagues revealed that HIF- $1 \alpha$ can directly bind the miR-27a promoter increasing the activity of some antiapoptotic pathways (i.e., the MDR1/P-gp, $\mathrm{Bcl}-2, \mathrm{LRP})$ and promoting multidrug resistance [65].

It is notable that while several miRNAs are directly induced by HIF, a great number of non-coding RNAs were found to be down-regulated in hypoxic conditions.

Liu et al. showed that in hepatocellular carcinoma miR-204 expression is inhibited by HIF- $1 \alpha$. These authors proved that hypoxia-induced down-regulation of miR-204 promotes malignant transformation through the up-regulation of Vasodilator-stimulated phosphoprotein (VASP); this is a regulator of cytoskeletal actin and cell migration, and its expression correlates with aggressive phenotype and metastasis both in vitro and in vivo [81]. MiR-33a and miR-199a-5p are found to be reduced under the regulation of HIF- $1 \alpha$ in HCC $[82,83]$. Li et al. proved that mirR-199a-5p inhibition by HIF- $1 \alpha$ regulates Warburg effect and induce tumour cell proliferation in hepatocellular carcinoma [83]. Also, miR-548an, a tumour suppressor miRNA, is down-regulated by HIF- $1 \alpha$ in pancreatic cancer cells, and it is involved in increasing vimentin level and facilitating the pancreatic tumorigenesis [73].

Intriguingly, several studies have reported hypoxamirs working as tumour suppressors e.g., the miR-145 or the miR-215 [62,92], thus suggesting the existence of an intricate network of interactors not yet fully revealed. To solve this, some aspects that have been neglected so far must be taken into account: (i) here we reviewed only a fraction of HIFinduced miRNA but several other miRNAs are induced under hypoxic condition in a HIF-independent manner, (ii) a single miRNA has numerous targets in the same cell, and (iii) hypoxia-induced lncRNAs can sequester multiple miRNAs preventing them from reaching their targets. 


\subsubsection{Hypoxia-Induced lncRNAs Participating in Tumour Growth}

The first reported hypoxia-inducible noncoding RNA is the transcript generated by the maternally imprinted oncofetal gene H19, for the full list see Table 2.

Table 2. List of hypoxia-responsive long non-coding RNAs involved in cell proliferation, apoptosis and cell cycle regulation.

\begin{tabular}{|c|c|c|c|c|c|c|}
\hline lncRNAs & Cancer Types & $\begin{array}{c}\text { Regulation } \\
\text { Hypoxia-Mediated }\end{array}$ & $\begin{array}{l}\text { Regulatory } \\
\text { Mechanism }\end{array}$ & Targets & Functions & References \\
\hline H19 & $\begin{array}{l}\text { colorectal cancer, } \\
\text { glioblastoma, } \\
\text { non-small cell lung } \\
\text { cancer and lung } \\
\text { cancer }\end{array}$ & upregulation & $\begin{array}{c}\text { direct } \\
\text { transcriptional } \\
\text { activation or } \\
\text { indirect } \\
\text { SP1-mediated } \\
\text { transcriptional } \\
\text { activation }\end{array}$ & NA & $\begin{array}{c}\text { mediates cancer } \\
\text { cell proliferation } \\
\text { upregulates cell } \\
\text { viability }\end{array}$ & [79,93-96] \\
\hline HOTAIR & $\begin{array}{c}\text { NSCLC, breast, } \\
\text { cervical and } \\
\text { endometrial cancer }\end{array}$ & upregulation & $\begin{array}{l}\text { transcriptional } \\
\text { activation }\end{array}$ & $\begin{array}{l}\text { JAM2, PCDH10, } \\
\text { PCDHB5 }\end{array}$ & $\begin{array}{l}\text { upregulates cell } \\
\text { viability }\end{array}$ & [97-100] \\
\hline UCA1 & $\begin{array}{l}\text { urinary bladder } \\
\text { cancer }\end{array}$ & upregulation & $\begin{array}{l}\text { transcriptional } \\
\text { activation }\end{array}$ & $\mathrm{BAX}$ & $\begin{array}{l}\text { mediates cancer } \\
\text { cell proliferation }\end{array}$ & {$[101]$} \\
\hline \multirow{3}{*}{ MALAT1 } & $\begin{array}{l}\text { hepatocellular } \\
\text { carcinoma }\end{array}$ & upregulation & $\begin{array}{l}\text { transcriptional } \\
\text { activation }\end{array}$ & miR-200a & $\begin{array}{l}\text { upregulates cell } \\
\text { proliferation }\end{array}$ & [102] \\
\hline & $\begin{array}{c}\text { lung } \\
\text { adenocarcinoma } \\
\text { cells }\end{array}$ & upregulation & $\begin{array}{l}\text { transcriptional } \\
\text { activation }\end{array}$ & $\begin{array}{l}\text { PTB-associated } \\
\text { splicing factor } \\
\text { protein (PSF) }\end{array}$ & $\begin{array}{l}\text { promotes } \\
\text { proliferation }\end{array}$ & [103] \\
\hline & myeloma cells & upregulation & $\begin{array}{l}\text { transcriptional } \\
\text { activation }\end{array}$ & $\begin{array}{l}\text { MALAT1 itself } \\
\text { through the } \\
\text { regulation of the } \\
\text { KDM3A (H3K9 } \\
\text { demethylating } \\
\text { enzyme) }\end{array}$ & $\begin{array}{l}\text { upregulates cell } \\
\text { proliferation }\end{array}$ & {$[104]$} \\
\hline NEAT1 & NSCLC & upregulation & $\begin{array}{l}\text { transcriptional } \\
\text { activation }\end{array}$ & miR-101-3p & $\begin{array}{l}\text { increases cell } \\
\text { proliferation }\end{array}$ & [105] \\
\hline LUCAT1 & colorectal cancer & upregulation & $\begin{array}{l}\text { transcriptional } \\
\text { activation }\end{array}$ & РТВP1 & $\begin{array}{l}\text { induces apoptosis } \\
\text { resistance, } \\
\text { prolonging G2/M } \\
\text { phase }\end{array}$ & [106] \\
\hline AGAP2-AS1 & $\begin{array}{c}\text { gastric cancer and } \\
\text { HCC }\end{array}$ & upregulation & $\begin{array}{l}\text { transcriptional } \\
\text { activation }\end{array}$ & miR-16-5p & $\begin{array}{l}\text { promotes cell } \\
\text { proliferation and } \\
\text { inhibits apoptosis }\end{array}$ & [107] \\
\hline PVT1 & $\begin{array}{l}\text { lung cancer cells, } \\
\text { nasopharyngeal } \\
\text { carcinoma }\end{array}$ & upregulation & NA & NA & $\begin{array}{l}\text { induces cell } \\
\text { proliferation }\end{array}$ & {$[108,109]$} \\
\hline HIF1A-AS2 & $\begin{array}{l}\text { breast cancer cells } \\
\text { and tumour }\end{array}$ & upregulation & $\begin{array}{l}\text { transcriptional } \\
\text { activation }\end{array}$ & $\operatorname{miR}-548 c-3 p$ & $\begin{array}{l}\text { induces cell } \\
\text { proliferation }\end{array}$ & [110] \\
\hline LET & $\begin{array}{l}\text { gallbladder cancer } \\
\text { cells }\end{array}$ & downregulation & NA & NA & $\begin{array}{l}\text { induces cell } \\
\text { viability and } \\
\text { proliferation }\end{array}$ & {$[111]$} \\
\hline Hincut 1 & $\begin{array}{l}\text { colorectal/breast } \\
\text { cancer cells }\end{array}$ & upregulation & $\begin{array}{l}\text { transcriptional } \\
\text { activation }\end{array}$ & NA & $\begin{array}{l}\text { upregulates } \\
\text { proliferation }\end{array}$ & [112] \\
\hline Linc-ROR & liver cancer cells & upregulation & & miR-145 & $\begin{array}{l}\text { promotes cell } \\
\text { survival }\end{array}$ & [113] \\
\hline BX111 & pancreatic cancer & upregulation & $\begin{array}{l}\text { transcriptional } \\
\text { activation }\end{array}$ & ZEB1 & $\begin{array}{l}\text { promotes cell } \\
\text { proliferation }\end{array}$ & {$[114]$} \\
\hline FALEC & prostate cancer & upregulation & $\begin{array}{l}\text { transcriptional } \\
\text { activation }\end{array}$ & & $\begin{array}{l}\text { promotes cell } \\
\text { proliferation }\end{array}$ & {$[115]$} \\
\hline NUTF2P3-001 & pancreatic cancer & upregulation & $\begin{array}{l}\text { transcriptional } \\
\text { activation }\end{array}$ & NA & $\begin{array}{l}\text { promotes cell } \\
\text { viability and } \\
\text { proliferation }\end{array}$ & [116] \\
\hline
\end{tabular}


It is well known that lncRNA H19 is expressed aberrantly in a wide range of tumours, promoting growth and dissemination (see review [117]); moreover, in different tumours, e.g., prostate cancer and glioblastoma, H19 expression was found significantly upregulated in hypoxia $[75,93,94,118]$. Firstly, Matouk et al. showed that H19 expression is dependent on the mutational status of the tumour suppressor p53. Specifically, during hypoxia, H19 expression is not induced in p53 wild type cells, while it is significantly increased in p53 null cells, indicating that lncRNA expression under hypoxia could be influenced by p53 mutation status [95]. Recently the crosstalk between $\operatorname{lncH} 19$ and p53 was further investigated in lung cancer, where it was demonstrated that lncH19, through upregulation of its intragenic miR-675, controls p53 expression [79,96].

Although several elements might contribute to controling lncH19 gene expression, it has been demonstrated that HIF-1 directly induces H19 expression [94].

The studies conducted by $\mathrm{Wu}$ and colleagues confirmed that HIF- $1 \alpha$ is actively involved in lncRNA H19 modulation in vitro and in vivo, proving that PTEN downregulation favours hypoxia-driven H19 induction. Moreover, they found that HIF- $1 \alpha$ may promote $\mathrm{H} 19$ expression by both directly binding to the $\mathrm{H} 19$ promoter and indirectly through SP1-mediated H19 transcriptional activation under hypoxia in glioblastoma cells [94].

Another of the lncRNAs induced by hypoxia is HOTAIR (HOX transcript antisense intergenic RNA). HOTAIR is an oncogenic lncRNA and a negative prognostic factor for several types of cancer, such as non-small cell lung cancer (NSCLC), breast, cervical, and endometrial cancer [97,98]. Zhou et al. reported that, in NSCLC cells, the upregulation of HOTAIR under hypoxia is directly dependent on HIF- $1 \alpha$, and that HIF-induced HOTAIR increases cell viability and invasion, while inhibits apoptosis of hypoxic cells [99]. Moreover, it was previously showed that HOTAIR can downregulate the expression of different tumour suppressor genes including JAM2, PCDH10, and PCDHB5 [100].

LncRNA-UCA1 (long non-coding transcript named urothelial carcinoma associated 1), in hypoxic urinary bladder cancer, is regulated in both HIF dependent and HIF independent manner with a role in hypoxia-mediated cancer cell proliferation and invasiveness. In particular, it was observed that LncRNA-UCA1 knockdown in hypoxia can reduce tumours' invasiveness by modulating apoptosis-associated proteins; LncRNA-UCA1 inhibition downregulates the anti-apoptotic protein Bcl-2 and upregulates the pro-apoptotic protein Bax [101]. Oncogenic functions of IncRNA-UCA1 have been reported in several cancer types, including colon cancer, breast cancer, and melanoma moreover, it is interesting to note that, as well demonstrated by Xue et al., this lnc can be transported by exosomes released by hypoxic bladder cancer, prompting tumour growth once internalized by normoxic cells [119].

The different data recently collected on the IncRNA MALAT1 (metastasis-associated lung adenocarcinoma transcript 1) are an example of how a single lncRNA can simultaneously activate several strategies that promote the same phenomenon, in this case, tumour progression.

Choudry et al. have first identified lncRNA MALAT1 as HIF-induced lncRNA in MCF7 breast cancer cells [47], while its mechanisms of action were identified more recently. In hepatocellular carcinoma, Zhou et al. demonstrated that hypoxia-induced MALAT1 participates in cells proliferation, apoptosis, migration, and invasion by sponging miR-200 [102]. It is well known in fact that upregulation of miR-200a reduces cell proliferation, migration, and invasion, while increases apoptosis. Interestingly, in lung adenocarcinoma cells A549, lncRNA MALAT-1 is significantly increased after hypoxic stimulation and promotes proliferation, migration and invasion cells through a different molecular mechanism [103]. The authors showed that upregulated lncRNA MALAT-1 interacts with PTB-associated splicing factor protein (PSF), this is responsible for epigenetic regulations of its target genes, such as the proto-oncogene $\mathrm{G}$ antigen 6 (GAGE6). The binding of MALAT-1 releases PSF from its downstream proto-oncogene and activates its transcription thus finally promoting proliferation, migration and invasion in A549 cells [106]. 
Moreover, once induced by hypoxia, MALAT1 regulates itself in myeloma. Ikeda and colleagues demonstrated that it could maintain and promote its expression under a hypoxic microenvironment through the regulation of the KDM3A (H3K9 demethylating enzyme) that in turn promotes MALAT1 transcription [104].

The IncRNA NEAT1, as reported by Choudhry et al., was significantly induced during hypoxia in MCF-7 cells by HIF direct binding on NEAT1 promoter [47]. NEAT1 is a pivotal architectural component of paraspeckles, which are involved in regulating gene/protein expression, either by protein sequestration or RNAs editing with subsequent retention in the nucleus. During hypoxia, this lncRNAs plays a role in controlling mRNAs involved in increased tumorigenesis, cell proliferation, cell survival and apoptosis inhibition [120]. Kong and colleagues identified miR-101-3p as a direct target of NEAT1. In particular, these authors observed that NEAT1 by sponging miR-101-3p can induce SOX9 upregulation that is involved in enhanced $\mathrm{Wnt} / \beta$-catenin signalling. In this study, the authors supposed that NEAT1 has an oncogenic role in NSCLC progression via miR-101-3p/SOX9/Wnt/ $\beta$-catenin axis [105].

Recently, Huan et al. identified the long non-coding LUCAT1 as a new player for hypoxic responses in CRC cells [106]. Under hypoxia, LUCAT1 is transcribed by HIF- $1 \alpha$ and it is involved in regulating cell growth, apoptosis, and DNA damage in CRC cells. Moreover, LUCAT1 overexpression induces chemoresistance in CRC cells both in vitro and in vivo. In particular, they observed that hypoxia-induced LUCAT1 is located in the nucleus of CRC cells, where it physically interacts with the RNA-binding protein PTBP1 modulating mRNA alternative splicing pathway of several PTB1-downstream transcripts including CD44. It is known, in many cancers, that alternative spliced CD44 (CD44v, retained form) can induce apoptosis resistance, prolonging G2/M phase, and DNA damage resistance. Thus, the authors identified the LUCAT1's role in alternative splicing control in cancer [106].

Another hypoxia-regulated lncRNA controlling cell proliferation is the LncRNA AGAP2-AS1, an antisense lncRNA located at 12q14.1 and dysregulated in cancers [121]. LncRNA AGAP2-AS1 promotes cell proliferation and inhibits apoptosis in gastric cancer and HCC $[107,122]$. It was demonstrated that AGAP2-AS1 sponges miR-16-5p that exerted a suppressive effect on cell proliferation, migration, invasion, and EMT progress of HCC cells. In addition, miR-16-5p can target Annexin A11 that, mediating the downstream phosphorylation of AKT, is associated with cancer progression, metastasis, apoptosis, and cell growth [107].

LncRNA PVT1 was recently found to induce cell proliferation through cell cycle modulation in many cancers $[123,124]$. Wang and colleagues confirmed that PVT1 was overexpressed in the hypoxic lung cancer cells and it was involved in cell growth and proliferation, demonstrating that PVT1 knockdown could significantly suppress lung cancer cell proliferation in vitro [108]. In another study, the results obtained by Wang and colleagues revealed that this lncRNA may act as an oncogene in nasopharyngeal carcinoma tumorigenesis [109].

Recently, another hypoxia-responsive lncRNA HIF1A-AS2 was revealed to be involved in a regulatory mechanism in tumorigenesis of breast cancer [110]. Guo and colleagues showed that HIF1A-AS2 was upregulated in breast cancer cells and tumour biopsies. Moreover, the reduction of HIF1A-AS2 significantly inhibited the cell proliferation, invasion, and angiogenesis both in vitro and in vivo. Furthermore, the results of their experiments in xenograft nude mice indicated that silencing of HIF1A-AS2 inhibited tumour growth and motility by targeting miR-548c-3p through regulating HIF-1 $\alpha$ / VEGF signalling pathway in vivo [110].

It is notable that some lncRNAs have been found down-regulated by HIF, an example is the lncRNA-LET [111], which usually functions as a tumour-suppressing element. Ma et al. reported that lncRNA-LET was significantly downregulated in gallbladder cancer cell lines under hypoxia, and its downregulation can induce cell viability and proliferation under hypoxic conditions. Furthermore, cell cycle analysis indicated that lncRNA-LET 
could inhibit gallbladder cancer cell proliferation by upregulating G0/G1 arrest and apoptosis [111]. Much of the data concerning the role of lncRNAs in driving the hypoxic response is centred on lncRNA-miRNAs interaction. It would be interesting, in this case, to analyse how the expression panel of cellular miRNAs varies in response to hypoxia-induced down-regulation of lncRNA-LET, this could lead to new mechanisms for the inhibition of the hypoxia-induced miRNAs.

\section{Feedback Loops between HIF and the Hypoxia-Induced Non-Coding RNA}

Nowadays, several studies reported that the reciprocal interplay that occurs between miRNAs and HIF transcription complex has a fundamental role in tumorigenesis. Bioinformatic analyses revealed that several miRNAs can target the $3^{\prime}$ UTR of HIFs' RNAs modulating their expression. Moreover, several studies have demonstrated that miRNAs could control HIF through an indirect mechanism. Hypoxia-induced miRNAs have been shown to target genes that may affect HIF- $1 \alpha$ stability, thus forming a positive feedback loop. So far, these miRNAs include the miR-210 miR-199a, miR-18a, miR-183 and miR-138.

As widely described in this review miR-210 is a significantly upregulated miRNA in almost all cancer cell lines under hypoxic condition. Increased miR-210, other than mediating hypoxic responses, can stabilize HIF expression. It was demonstrated that miR210 targets the electron transport chain through SDHD (succinate dehydrogenase complex, subunit D), inducing accumulation of succinate that, in turn, inhibits Prolyl hydroxylase domain enzymes (PHD) and stabilizes HIF- $1 \alpha$, thus forming a positive-autoregulatory loop [125]. More recently, Du et al. demonstrated that miR-210-3p targets GPD1L (glycerol3-phosphate dehydrogenase 1-like) and consequently affects HIF1 $\alpha$ stability inducing an effect similar to that observed with SDHD inhibition [61].

Data collected from prostate cancer demonstrated that hypoxia-induced overexpression of miR-182 can result in reduced levels of two negative regulators of HIF1 signalling: the PHD and the Factor inhibiting HIF-1 (FIH1) [126].

Also, the miR-675-5p, which is embedded in hypoxia-induced long non-coding RNA $\mathrm{H} 19$, is required to sustain the activity of HIF- $1 \alpha$ at least in Glioblastoma and Colorectal cancer models [75,77]. It was demonstrated that miR675-5p is a hypoxia-regulated miRNA essential for hypoxia establishment and involved in hypoxia-mediated angiogenesis. Specifically, we demonstrated that miR675-5p inhibition during hypoxia affects HIF- $1 \alpha$ activity. In particular, the proposed model indicated that miR675-5p sustains HIF- $1 \alpha$ and VEGF mRNA stabilization trough the involvement of HuR, an RNA binding protein that binds HIF- $1 \alpha$ and VEGF mRNAs, increasing their stability.

Another two positive feedback loops have been found to coexist in multidrug-resistant hepatocellular cancer cells, HIF-1 $\alpha$ /miR-183/IDH2/HIF- $1 \alpha$ and HIF- $1 \alpha /$ miR-183/SOCS6/ p-STAT3/HIF-1 $\alpha$, which may modulate HIF- $1 \alpha$ protein [127].

Recently, in silico bioinformatics analysis showed that hypoxia-upregulates miR526b/ miR655 stabilize HIF proteins targeting the transcription factors NR2C2, SALL4, and ZNF207 that, in turn, regulate PTEN (a negative regulator of HIF- $1 \alpha$ ) and NFKB1 (positive regulator of COX-2 and EP4) [128].

An interesting loop is that mediated by the down-regulation of two miRNAs: miR-103 and miR-107 [129,130], that do not target HIF- $1 \alpha$ but ARNT, the binding partner of the HIF complex. Although widely considered to be constitutively expressed, ARNT was found to be regulated by hypoxia in several models where it confers drug-resistance and tumour growth [131-133]. Moreover, Mandl et al. demonstrated that ARNT over-expression, alone, can stabilize HIF-1a and activate HRE-equipped genes in normoxia, providing evidence that little is known yet about the role of ARNTs in regulating the hypoxic response [131].

In the last years, to identify new strategies to block hypoxic responses, many miRNAs have been tested for targeting HIF activity. Indeed, according to a recent study, in CRC cell lines it was suggested that the ectopic expression of miR-1 has an anti-proliferative effect by targeting HIF- $1 \alpha$ [134]. In pancreatic cancer cells, over-expression of miR-142, normally reduced under hypoxic condition, significantly affects cell proliferation and migration by 
downregulating HIF-1 $\alpha$ [135]. In another study, Liu et al. showed that miR-186/ HIF-1 $\alpha$ axis is fundamental to the proliferation of gastric cancer cells, and that upregulation of miR-186 can inhibit tumour cell proliferation through targeting HIF-1 $\alpha$ [136].

Also, several lncRNAs have been found involved in the positive loops stabilizing HIF. Among this, it is possible to identify two major groups: (i) the lncRNAs that sponge miRNAs targeting HIFs and (ii) the IncRNAs that directly participate in HIF genes transcription or mRNA stabilization. However, it is notable that some lncs have been identified to work through both mechanisms, for example, the plasmacytoma variant translocation 1 (PVT1).

Firstly, Wang and collaborators revealed a connection among lnc-PVT1, miR-199a-5p, and HIF- $1 \alpha$ in cell response to hypoxia; they demonstrated that hypoxia-induced PVT1 could function as a molecular sponge inhibiting miR-199a-5p and thus promoting the expression of its endogenous target HIF- $1 \alpha$ [108]. Further studies conducted on nasopharyngeal carcinoma, proposed a new putative mechanism by which PVT1 could stabilize HIF-1 $\alpha$ [109]; here, the authors demonstrated that the lncRNA functions as a scaffold for the chromatin modification factor KAT2A, which stabilizes HIF- $1 \alpha$ via H3K9ac/TIF1 $\beta$ complex-mediated NF90 (a double-stranded RNA-binding protein) transcriptional activation [109].

Several lncRNAs work as competitive endogenous RNAs, modulating the amount of miRNA available to interact with HIF's messenger. In colorectal cancer, the hypoxiainduced lncRNAs XIST and LINC00511 down-regulate respectively the miR-93-5p and the miR-153-5p, which both have HIF-1 $\alpha$ mRNA among their targets $[137,138]$. In nasopharyngeal carcinoma, the hypoxia-indued lncRNA DLX6-AS1 (long-chain non-coding growth stasis specific protein 6 antisense RNA1) stabilizes HIF- $1 \alpha$ mRNA sponging the miR-199a-5p [139]. A further positive molecular loop is that mediated by the expression of the hypoxia-induced H19 that stabilizes HIF- $1 \alpha$ mRNA competing with the miR-138 [140].

Concerning the lncRNAs that directly modulate HIF1 expression, in nasopharyngeal carcinoma HIF- $1 \alpha$ mRNA stability is mediated by the lncRNA DANCR (differentiation antagonizing non-protein coding RNA); this is required for the interaction between HIF- $1 \alpha$ mRNA and the complex NF90/NF45 which was found increase HIF- $1 \alpha$ mRNA stability [141]

Moreover, some lncRNAs, down-regulated during hypoxic conditions, have been found able to destabilize HIFs.

In pancreatic cancer cells, Liu et al. showed that HIF transcriptionally downregulates lnc-RNA-CF129 expression by recruiting HDAC1 to its the promoter [142]. Interestingly, the authors demonstrated that CF129 can down-regulates the transcription factors FOXC2, that promotes HIF- $1 \alpha$ expression [142].

Another negative regulator of HIF- $1 \alpha$ is the lncRNA HITT (HIF- $1 \alpha$ inhibitor at translation levels) that plays roles in modulating hypoxia-mediated angiogenesis and tumour growth in vivo. Recently, Hu and collaborators demonstrated that HITT inhibits HIF- $1 \alpha$ transcription by guiding Ezh2 through the formation of an RNA-DNA triplex with the HIF- $1 \alpha$ promoter. The occupancy of Ezh2 and its substrate H3K27me3 on the HIF-1 $\alpha$ promoter is detected under normoxia and is reduced by hypoxia [143].

Park and his collaborator identified a new way by which the prolyl isomerase Pin1 plays a role in the regulation of HIF- $1 \alpha$. Interestingly they found that the PNI1 transcript variant 2 inhibits HIF- $1 \alpha$ transcription hiding the binding site for NFAT on the HIF1A promoter [144].

\section{Conclusions}

In conclusion, we reviewed here the most recent findings of hypoxia-induced noncoding RNA supporting HIF in the cell growth control. The data collected revealed a complex network of molecular interactors activated directly by the HIF complex in oxygen deficiency. The picture becomes even more complicated if we add to these the HIF-independent molecular pathways, which also take part in the hypoxic response. More 
detailed knowledge of these pathways and their interactions is necessary to identify new and more effective therapeutic targets.

Author Contributions: Conceptualization, M.M.B. and A.C., writing-original draft preparation, M.M.B., C.Z., and A.C., review and editing, R.A. and A.C. All authors have read and agreed to the published version of the manuscript.

Funding: "This research was funded by AIRC under MFAG 2017-ID. 19982 project-P.I. Alice Conigliaro" and "The APC was funded AIRC under MFAG 2017-ID. 19982 project-".

Conflicts of Interest: The authors declare no conflict of interest.

\section{References}

1. Najafi, M.; Farhood, B.; Mortezaee, K.; Kharazinejad, E.; Majidpoor, J.; Ahadi, R. Hypoxia in solid tumors: A key promoter of cancer stem cell (CSC) resistance. J. Cancer Res. Clin. Oncol. 2020, 146, 19-31. [CrossRef]

2. Kim, M.-C.; Hwang, S.-H.; Kim, N.-Y.; Lee, H.-S.; Ji, S.; Yang, Y.; Kim, Y. Hypoxia promotes acquisition of aggressive phenotypes in human malignant mesothelioma. BMC Cancer 2018, 18, 819. [CrossRef]

3. Xiang, L.; Semenza, G.L. Hypoxia-inducible factors promote breast cancer stem cell specification and maintenance in response to hypoxia or cytotoxic chemotherapy. Adv. Cancer Res. 2019, 141, 175-212. [CrossRef] [PubMed]

4. Wu, D.; Potluri, N.; Lu, J.; Kim, Y.; Rastinejad, F. Structural integration in hypoxia-inducible factors. Nat. Cell Biol. 2015, 524, 303-308. [CrossRef] [PubMed]

5. Smythies, J.A.; Sun, M.; Masson, N.; Salama, R.; Simpson, P.D.; Murray, E.; Neumann, V.; Cockman, M.E.; Choudhry, H.; Ratcliffe, P.J.; et al. Inherent DNA -binding specificities of the HIF- $1 \alpha$ and HIF-2 $\alpha$ transcription factors in chromatin. EMBO Rep. 2019, 20. [CrossRef]

6. Maynard, M.A.; Evans, A.J.; Hosomi, T.; Hara, S.; Jewett, M.A.S.; Ohh, M. Human HIF-3 $\alpha 4$ is a dominant-negative regulator of HIF-1 and is down-regulated in renal cell carcinoma. FASEB J. 2005, 19, 1396-1406. [CrossRef] [PubMed]

7. Yamashita, T.; Ohneda, O.; Nagano, M.; Iemitsu, M.; Makino, Y.; Tanaka, H.; Miyauchi, T.; Goto, K.; Ohneda, K.; Fujii-Kuriyama, Y.; et al. Abnormal Heart Development and Lung Remodeling in Mice Lacking the Hypoxia-Inducible Factor-Related Basic Helix-Loop-Helix PAS Protein NEPAS. Mol. Cell. Biol. 2007, 28, 1285-1297. [CrossRef]

8. Kobayashi, S.; Yamashita, T.; Ohneda, K.; Nagano, M.; Kimura, K.; Nakai, H.; Poellinger, L.; Ohneda, O. Hypoxia-inducible factor- $3 \alpha$ promotes angiogenic activity of pulmonary endothelial cells by repressing the expression of the VE-cadherin gene. Genes Cells 2015, 20, 224-241. [CrossRef]

9. Tolonen, J.-P.; Heikkilä, M.; Malinen, M.; Lee, H.-M.; Palvimo, J.J.; Wei, G.-H.; Myllyharju, J. A long hypoxia-inducible factor 3 isoform 2 is a transcription activator that regulates erythropoietin. Cell. Mol. Life Sci. 2020, 77, 3627-3642. [CrossRef]

10. Depping, R.; Jelkmann, W.; Kosyna, F.K. Nuclear-cytoplasmatic shuttling of proteins in control of cellular oxygen sensing. J. Mol. Med. 2015, 93, 599-608. [CrossRef] [PubMed]

11. Semenza, G.L. Hypoxia-inducible factors: Coupling glucose metabolism and redox regulation with induction of the breast cancer stem cell phenotype. EMBO J. 2017, 36, 252-259. [CrossRef]

12. Lv, X.; Li, J.; Zhang, C.; Hu, T.; Li, S.; He, S.; Yan, H.; Tan, Y.; Lei, M.; Wen, M.; et al. The role of hypoxia-inducible factors in tumor angiogenesis and cell metabolism. Genes Dis. 2017, 4, 19-24. [CrossRef]

13. Hubbi, M.E.; Semenza, G.L. Regulation of cell proliferation by hypoxia-inducible factors. Am. J. Physiol.-Cell Physiol. 2015, 309, C775-C782. [CrossRef]

14. Vaddi, D.R.; Piao, L.; Khan, S.A.; Wang, N.; Prabhakar, N.R.; Nanduri, J. Hypoxia induced hERG trafficking defect linked to cell cycle arrest in SH-SY5Y cells. PLoS ONE 2019, 14, e0215905. [CrossRef] [PubMed]

15. Ha, M.; Kim, V.N. Regulation of microRNA biogenesis. Nat. Rev. Mol. Cell Biol. 2014, 15, 509-524. [CrossRef]

16. Han, J.; Lee, Y.; Yeom, K.-H.; Kim, Y.-K.; Jin, H.; Kim, V.N. The Drosha-DGCR8 complex in primary microRNA processing. Genes Dev. 2004, 18, 3016-3027. [CrossRef]

17. Berg, A.V.D.; Mols, J.; Han, J. RISC-target interaction: Cleavage and translational suppression. Biochim. Biophys. Acta BBA Bioenerg. 2008, 1779, 668-677. [CrossRef]

18. Place, R.F.; Li, L.-C.; Pookot, D.; Noonan, E.J.; Dahiya, R. MicroRNA-373 induces expression of genes with complementary promoter sequences. Proc. Natl. Acad. Sci. USA 2008, 105, 1608-1613. [CrossRef] [PubMed]

19. Orang, A.V.; Safaralizadeh, R.; Kazemzadeh-Bavili, M. Mechanisms of miRNA-Mediated Gene Regulation from Common Downregulation to mRNA-Specific Upregulation. Int. J. Genom. 2014, 2014, 970607. [CrossRef]

20. De Sousa, M.C.; Gjorgjieva, M.; Dolicka, D.; Sobolewski, C.; Foti, M. Deciphering miRNAs' Action through miRNA Editing. Int. J. Mol. Sci. 2019, 20, 6249. [CrossRef] [PubMed]

21. Schmitz, S.U.; Grote, P.; Herrmann, B.G. Mechanisms of long noncoding RNA function in development and disease. Cell. Mol. Life Sci. 2016, 73, 2491-2509. [CrossRef] [PubMed]

22. Ma, L.; Bajic, V.B.; Zhang, Z. On the classification of long non-coding RNAs. RNA Biol. 2013, 10, 924-933. [CrossRef]

23. Quinn, J.J.; Chang, H.Y. Unique features of long non-coding RNA biogenesis and function. Nat. Rev. Genet. 2016, 17, 47-62. [CrossRef] 
24. Krchňáková, Z.; Thakur, P.K.; Krausová, M.; Bieberstein, N.; Haberman, N.; Müller-McNicoll, M.; Staněk, D. Splicing of long non-coding RNAs primarily depends on polypyrimidine tract and $5^{\prime}$ splice-site sequences due to weak interactions with SR proteins. Nucleic Acids Res. 2019, 47, 911-928. [CrossRef] [PubMed]

25. Jiang, W.; Agrawal, D.K.; Boosani, C.S. Non-coding RNAs as Epigenetic Gene Regulators in Cardiovascular Diseases. Adv. Exp. Med. Biol. 2020, 1229, 133-148. [CrossRef]

26. Zhang, X.; Wang, W.; Zhu, W.; Dong, J.; Cheng, Y.; Yin, Z.; Shen, F. Mechanisms and Functions of Long Non-Coding RNAs at Multiple Regulatory Levels. Int. J. Mol. Sci. 2019, 20, 5573. [CrossRef]

27. Li, X.; Guo, G.; Lu, M.; Chai, W.; Li, Y.; Tong, X.; Li, J.; Jia, X.; Liu, W.; Qi, D.; et al. Long Noncoding RNA Lnc-MxA Inhibits Beta Interferon Transcription by Forming RNA-DNA Triplexes at Its Promoter. J. Virol. 2019, 93. [CrossRef]

28. Romero-Barrios, N.; Legascue, M.F.; Benhamed, M.; Ariel, F.; Crespi, M. Splicing regulation by long noncoding RNAs. Nucleic Acids Res. 2018, 46, 2169-2184. [CrossRef]

29. Jonas, K.; Calin, G.A.; Pichler, M. RNA-Binding Proteins as Important Regulators of Long Non-Coding RNAs in Cancer. Int. J. Mol. Sci. 2020, 21, 2969. [CrossRef]

30. Zhang, J.; Liu, L.; Li, J.; Le, T.D. LncmiRSRN: Identification and analysis of long non-coding RNA related miRNA sponge regulatory network in human cancer. Bioinformatics 2018, 34, 4232-4240. [CrossRef] [PubMed]

31. Salzman, J. Circular RNA Expression: Its Potential Regulation and Function. Trends Genet. 2016, 32, 309-316. [CrossRef] [PubMed]

32. Vo, J.N.; Cieslik, M.; Zhang, Y.; Shukla, S.; Xiao, L.; Zhang, Y.; Wu, Y.-M.; Dhanasekaran, S.M.; Engelke, C.G.; Cao, X.; et al. The Landscape of Circular RNA in Cancer. Cell 2019, 176, 869-881. [CrossRef]

33. Jeck, W.R.; Sorrentino, J.A.; Wang, K.; Slevin, M.K.; Burd, C.E.; Liu, J.; Marzluff, W.F.; Sharpless, N.E. Circular RNAs are abundant, conserved, and associated with ALU repeats. RNA 2012, 19, 141-157. [CrossRef] [PubMed]

34. Abe, N.; Matsumoto, K.; Nishihara, M.; Nakano, Y.; Shibata, A.; Maruyama, H.; Shuto, S.; Matsuda, A.; Yoshida, M.; Ito, Y.; et al. Rolling Circle Translation of Circular RNA in Living Human Cells. Sci. Rep. 2015, 5, 16435. [CrossRef]

35. Legnini, I.; Di Timoteo, G.; Rossi, F.; Morlando, M.; Briganti, F.; Sthandier, O.; Fatica, A.; Santini, T.; Andronache, A.; Wade, M.; et al. Circ-ZNF609 Is a Circular RNA that Can Be Translated and Functions in Myogenesis. Mol. Cell 2017, 66, 22-37. [CrossRef]

36. Lei, M.; Zheng, G.; Ning, Q.; Zheng, J.; Dong, D. Translation and functional roles of circular RNAs in human cancer. Mol. Cancer 2020, 19, 1-9. [CrossRef]

37. Li, Z.; Huang, C.; Bao, C.; Chen, L.; Lin, M.; Wang, X.; Zhong, G.; Yu, B.; Hu, W.; Dai, L.; et al. Exon-intron circular RNAs regulate transcription in the nucleus. Nat. Struct. Mol. Biol. 2015, 22, 256-264. [CrossRef] [PubMed]

38. Zhang, Y.; Zhang, X.-O.; Chen, T.; Xiang, J.-F.; Yin, Q.-F.; Xing, Y.-H.; Zhu, S.; Yang, L.; Chen, L.-L. Circular Intronic Long Noncoding RNAs. Mol. Cell 2013, 51, 792-806. [CrossRef] [PubMed]

39. Lu, Z.; Filonov, G.S.; Noto, J.J.; Schmidt, C.A.; Hatkevich, T.L.; Wen, Y.; Jaffrey, S.R.; Matera, A.G. Metazoan tRNA introns generate stable circular RNAs in vivo. RNA 2015, 21, 1554-1565. [CrossRef] [PubMed]

40. Hansen, T.B.; Jensen, T.I.; Clausen, B.H.; Bramsen, J.B.; Finsen, B.; Damgaard, C.K.; Kjems, J. Natural RNA circles function as efficient microRNA sponges. Nat. Cell Biol. 2013, 495, 384-388. [CrossRef]

41. Lasda, E.; Parker, R. Circular RNAs: Diversity of form and function. RNA 2014, 20, 1829-1842. [CrossRef] [PubMed]

42. Xu, M.; Xie, F.; Tang, X.; Wang, T.; Wang, S. Insights into the role of circular RNA in macrophage activation and fibrosis disease. Pharmacol. Res. 2020, 156, 104777. [CrossRef]

43. Huang, A.; Zheng, H.; Wu, Z.; Chen, M.; Huang, Y. Circular RNA-protein interactions: Functions, mechanisms, and identification. Theranostics 2020, 10, 3503-3517. [CrossRef] [PubMed]

44. Camps, C.; Saini, H.K.; Mole, D.R.; Choudhry, H.; Reczko, M.; Guerra-Assunção, J.A.; Tian, Y.-M.; Buffa, F.M.; Harris, A.L.; Hatzigeorgiou, A.G.; et al. Integrated analysis of microRNA and mRNA expression and association with HIF binding reveals the complexity of microRNA expression regulation under hypoxia. Mol. Cancer 2014, 13, 28. [CrossRef] [PubMed]

45. Nallamshetty, S.; Chan, S.Y.; Loscalzo, J. Hypoxia: A master regulator of microRNA biogenesis and activity. Free Radic. Biol. Med. 2013, 64, 20-30. [CrossRef] [PubMed]

46. Slemc, L.; Kunej, T. Transcription factor HIF1A: Downstream targets, associated pathways, polymorphic hypoxia response element (HRE) sites, and initiative for standardization of reporting in scientific literature. Tumor Biol. 2016, 37, 14851-14861. [CrossRef] [PubMed]

47. Choudhry, H.; Schödel, J.; Oikonomopoulos, S.; Camps, C.; Grampp, S.; Harris, A.L.; Ratcliffe, P.J.; Ragoussis, J.; Mole, D.R. Extensive regulation of the non-coding transcriptome by hypoxia: Role of HIF in releasing paused RNA pol2. EMBO Rep. 2014, 15, 70-76. [CrossRef]

48. Lai, H.-H.; Li, J.-N.; Wang, M.-Y.; Huang, H.-Y.; Croce, C.M.; Sun, H.-L.; Lyu, Y.-J.; Kang, J.-W.; Chiu, C.-F.; Hung, M.-C.; et al. HIF-1 $\alpha$ promotes autophagic proteolysis of Dicer and enhances tumor metastasis. J. Clin. Investig. 2017, 128, 625-643. [CrossRef]

49. Wang, Y.; Liu, X.; Zhang, H.; Sun, L.; Zhou, Y.; Jin, H.; Zhang, H.; Zhang, H.; Liu, J.; Guo, H.; et al. Hypoxia-inducible lncRNA-AK058003 promotes gastric cancer metastasis by targeting $\gamma$-synuclein. Neoplasia 2014, 16, 1094-1106. [CrossRef]

50. He, K.; Wang, P. Unregulated long non-coding RNA-AK058003 promotes the proliferation, invasion and metastasis of breast cancer by regulating the expression levels of the $\gamma$-synuclein gene. Exp. Ther. Med. 2015, 9, 1727-1732. [CrossRef] [PubMed]

51. Cheng, X.; Qiu, J.; Wang, S.; Yang, Y.; Guo, M.; Wang, D.; Luo, Q.; Xu, L. Comprehensive circular RNA profiling identifies CircFAM120A as a new biomarker of hypoxic lung adenocarcinoma. Ann. Transl. Med. 2019, 7, 442. [CrossRef] [PubMed] 
52. Di Liddo, A.; Machado, C.D.O.F.; Fischer, S.; Ebersberger, S.; Heumüller, A.W.; E Weigand, J.; Müller-McNicoll, M.; Zarnack, K. A combined computational pipeline to detect circular RNAs in human cancer cells under hypoxic stress. J. Mol. Cell Biol. 2019, 11, 829-844. [CrossRef] [PubMed]

53. Wei, Y.; Zhang, Y.; Meng, Q.; Cui, L.; Xu, C. Hypoxia-induced circular RNA has_circRNA_403658 promotes bladder cancer cell growth through activation of LDHA. Am. J. Transl Res. 2019, 11, 6838-6849.

54. Wang, Z.; Deng, M.; Liu, Z.; Wu, S. Hypoxia-induced miR-210 promoter demethylation enhances proliferation, autophagy and angiogenesis of schwannoma cells. Oncol. Rep. 2017, 37, 3010-3018. [CrossRef]

55. Chio, C.-C.; Lin, J.-W.; Cheng, H.-A.; Chiu, W.-T.; Wang, Y.-H.; Wang, J.-J.; Hsing, C.-H.; Chen, R.-M. MicroRNA-210 targets antiapoptotic Bcl-2 expression and mediates hypoxia-induced apoptosis of neuroblastoma cells. Arch. Toxicol. 2012, 87, 459-468 [CrossRef]

56. Zhang, Z.; Sun, H.; Dai, H.; Walsh, R.M.; Imakura, M.; Schelter, J.; Burchard, J.; Dai, X.; Chang, A.N.; Diaz, R.L.; et al. MicroRNA miR-210 modulates cellular response to hypoxia through the MYC antagonist MNT. Cell Cycle 2009, 8, 2756-2768. [CrossRef]

57. Yang, W.; Wei, J.; Guo, T.; Shen, Y.; Liu, F. Knockdown of miR-210 decreases hypoxic glioma stem cells stemness and radioresistance. Exp. Cell Res. 2014, 326, 22-35. [CrossRef]

58. Li, L.; Huang, K.; You, Y.; Fu, X.; Hu, L.; Song, L.; Meng, Y. Hypoxia-induced miR-210 in epithelial ovarian cancer enhances cancer cell viability via promoting proliferation and inhibiting apoptosis. Int. J. Oncol. 2014, 44, 2111-2120. [CrossRef]

59. Yang, W.; Sun, T.; Cao, J.; Liu, F.; Tian, Y.; Zhu, W. Downregulation of miR-210 expression inhibits proliferation, induces apoptosis and enhances radiosensitivity in hypoxic human hepatoma cells in vitro. Exp. Cell Res. 2012, 318, 944-954. [CrossRef]

60. Xue, Y.-X.; Shang, C.; Hong, Y.; Guo, Y.; Liu, Y.-H. MiR-210 Up-Regulation Inhibits Proliferation and Induces Apoptosis in Glioma Cells by Targeting SIN3A. Med. Sci. Monit. 2014, 20, 2571-2577. [CrossRef] [PubMed]

61. Du, Y.; Wei, N.; Ma, R.; Jiang, S.; Song, D. A miR-210-3p regulon that controls the Warburg effect by modulating HIF-1 $\alpha$ and p53 activity in triple-negative breast cancer. Cell Death Dis. 2020, 11, 731. [CrossRef]

62. Blick, C.; Ramachandran, A.V.; McCormick, R.; Wigfield, S.; Cranston, D.; Catto, J.W.F.; Harris, A.L. Identification of a hypoxiaregulated miRNA signature in bladder cancer and a role for miR-145 in hypoxia-dependent apoptosis. Br. J. Cancer 2015, 113, 634-644. [CrossRef]

63. Nagpal, N.; Ahmad, H.M.; Chameettachal, S.; Sundar, D.; Ghosh, S.; Kulshreshtha, R. HIF-inducible miR-191 promotes migration in breast cancer through complex regulation of TGF $\beta$-signaling in hypoxic microenvironment. Sci. Rep. 2015, 5, 9650. [CrossRef] [PubMed]

64. Zhao, J.; Qiao, C.-R.; Ding, Z.; Sheng, Y.-L.; Li, X.-N.; Yang, Y.; Zhu, D.-Y.; Zhang, C.-Y.; Liu, D.-L.; Wu, K.; et al. A novel pathway in NSCLC cells: miR-191, targeting NFIA, is induced by chronic hypoxia, and promotes cell proliferation and migration. Mol. Med. Rep. 2017, 15, 1319-1325. [CrossRef] [PubMed]

65. Zhao, Q.; Li, Y.; Tan, B.-B.; Fan, L.-Q.; Yang, P.-G.; Tian, Y. HIF-1 $\alpha$ Induces Multidrug Resistance in Gastric Cancer Cells by Inducing MiR-27a. PLoS ONE 2015, 10, e0132746. [CrossRef] [PubMed]

66. Seok, J.-K.; Lee, S.H.; Kim, M.J.; Lee, Y.-M. MicroRNA-382 induced by HIF-1 $\alpha$ is an angiogenic miR targeting the tumor suppressor phosphatase and tensin homolog. Nucleic Acids Res. 2014, 42, 8062-8072. [CrossRef]

67. Zhang, D.; Shi, Z.; Li, M.; Mi, J. Hypoxia-induced miR-424 decreases tumor sensitivity to chemotherapy by inhibiting apoptosis. Cell Death Dis. 2014, 5, e1301. [CrossRef]

68. Chen, H.-Y.; Lin, Y.-M.; Chung, H.-C.; Lang, Y.-D.; Lin, C.-J.; Huang, J.; Wang, W.-C.; Lin, F.-M.; Chen, Z.; Huang, H.-D.; et al. miR-103/107 Promote Metastasis of Colorectal Cancer by Targeting the Metastasis Suppressors DAPK and KLF4. Cancer Res. 2012, 72, 3631-3641. [CrossRef]

69. Mace, T.A.; Collins, A.L.; Wojcik, S.E.; Croce, C.M.; Lesinski, G.B.; Bloomston, M. Hypoxia induces the overexpression of microRNA-21 in pancreatic cancer cells. J. Surg. Res. 2013, 184, 855-860. [CrossRef]

70. Song, L.; Liu, S.; Zhang, L.; Yao, H.; Gao, F.; Xu, D.; Lili, S. MiR-21 modulates radiosensitivity of cervical cancer through inhibiting autophagy via the PTEN/Akt/HIF-1 $\alpha$ feedback loop and the Akt-mTOR signaling pathway. Tumor Biol. 2016, 37, 12161-12168. [CrossRef]

71. He, C.; Wang, L.; Zhang, J.; Xu, H. Hypoxia-inducible microRNA-224 promotes the cell growth, migration and invasion by directly targeting RASSF8 in gastric cancer. Mol. Cancer 2017, 16, 35. [CrossRef]

72. Blick, C.; Ramachandran, A.; Wigfield, S.; McCormick, R.; Jubb, A.M.; Buffa, F.M.; Turley, H.; A Knowles, M.; Cranston, D.; Catto, J.W.F.; et al. Hypoxia regulates FGFR3 expression via HIF- $1 \alpha$ and miR-100 and contributes to cell survival in non-muscle invasive bladder cancer. Br. J. Cancer 2013, 109, 50-59. [CrossRef]

73. Zhu, S.; He, C.; Deng, S.; Li, X.; Cui, S.; Zeng, Z.; Liu, M.; Zhao, S.; Chen, J.; Jin, Y.; et al. MiR-548an, Transcriptionally Downregulated by HIF1 $\alpha /$ HDAC1, Suppresses Tumorigenesis of Pancreatic Cancer by Targeting Vimentin Expression. Mol. Cancer Ther. 2016, 15, 2209-2219. [CrossRef]

74. He, M.; Wang, Q.-Y.; Yin, Q.-Q.; Tang, J.; Lu, Y.; Zhou, C.-X.; Duan, C.-W.; Hong, D.-L.; Tanaka, T.; Chen, G.-Q.; et al. HIF-1 $\alpha$ downregulates miR-17/20a directly targeting p21 and STAT3: A role in myeloid leukemic cell differentiation. Cell Death Differ. 2012, 20, 408-418. [CrossRef]

75. Dico, A.L.; Costa, V.; Martelli, C.; Diceglie, C.; Rajata, F.; Rizzo, A.; Mancone, C.; Tripodi, M.; Ottobrini, L.; Alessandro, R.; et al. MiR675-5p Acts on HIF-1 $\alpha$ to Sustain Hypoxic Responses: A New Therapeutic Strategy for Glioma. Theranostics 2016, 6, 1105-1118. [CrossRef] [PubMed] 
76. Shi, Y.; Wang, Y.; Luan, W.; Wang, P.; Tao, T.; Zhang, J.; Qian, J.; Liu, N.; You, Y. Long Non-Coding RNA H19 Promotes Glioma Cell Invasion by Deriving miR-675. PLoS ONE 2014, 9, e86295. [CrossRef]

77. Costa, V.; Dico, A.L.; Rizzo, A.; Rajata, F.; Tripodi, M.; Alessandro, R.; Conigliaro, A. MiR-675-5p supports hypoxia induced epithelial to mesenchymal transition in colon cancer cells. Oncotarget 2017, 8, 24292-24302. [CrossRef]

78. Saieva, L.; Barreca, M.M.; Zichittella, C.; Prado, M.G.; Tripodi, M.; Alessandro, R.; Conigliaro, A. Hypoxia-Induced miR-675-5p Supports $\beta$-Catenin Nuclear Localization by Regulating GSK3- $\beta$ Activity in Colorectal Cancer Cell Lines. Int. J. Mol. Sci. 2020, 21, 3832. [CrossRef] [PubMed]

79. Zheng, Z.; Wu, D.; Fan, S.; Zhang, Z.; Chen, G.; Lu, J. Upregulation of miR-675-5p induced by lncRNA H19 was associated with tumor progression and development by targeting tumor suppressor p53 in non-small cell lung cancer. J. Cell. Biochem. 2019, 120, 18724-18735. [CrossRef]

80. Ge, X.; Liu, X.; Lin, F.; Li, P.; Liu, K.; Geng, R.; Dai, C.; Lin, Y.; Tang, W.; Wu, Z.; et al. MicroRNA-421 regulated by HIF-1 $\alpha$ promotes metastasis, inhibits apoptosis, and induces cisplatin resistance by targeting E-cadherin and caspase- 3 in gastric cancer. Oncotarget 2016, 7, 24466-24482. [CrossRef]

81. Liu, Z.; Wang, Y.; Dou, C.; Xu, M.; Sun, L.; Wang, L.; Yao, B.; Li, Q.; Yang, W.; Tu, K.; et al. Hypoxia-induced up-regulation of VASP promotes invasiveness and metastasis of hepatocellular carcinoma. Theranostics 2018, 8, 4649-4663. [CrossRef] [PubMed]

82. Guo, X.F.; Wang, A.Y.; Liu, J. HIFs-MiR-33a-Twsit1 axis can regulate invasiveness of hepatocellular cancer cells. Eur. Rev. Med. Pharmacol. Sci. 2016, 20, 3011-3016.

83. Li, B.; He, L.; Zuo, D.; He, W.; Wang, Y.; Zhang, Y.; Liu, W.; Yuan, Y. Mutual Regulation of MiR-199a-5p and HIF-1 $\alpha$ Modulates the Warburg Effect in Hepatocellular Carcinoma. J. Cancer 2017, 8, 940-949. [CrossRef] [PubMed]

84. Huang, X.; Ding, L.; Bennewith, K.L.; Tong, R.T.; Welford, S.M.; Ang, K.K.; Story, M.; Le, Q.-T.; Giaccia, A.J. Hypoxia-Inducible mir-210 Regulates Normoxic Gene Expression Involved in Tumor Initiation. Mol. Cell 2009, 35, 856-867. [CrossRef] [PubMed]

85. Pasculli, B.; Barbano, R.; Rendina, M.; Fontana, A.; Copetti, M.; Mazza, T.; Valori, V.M.; Morritti, M.; Maiello, E.; Graziano, P.; et al. Hsa-miR-210-3p expression in breast cancer and its putative association with worse outcome in patients treated with Docetaxel. Sci. Rep. 2019, 9, 14913. [CrossRef] [PubMed]

86. Osugi, J.; Kimura, Y.; Owada, Y.; Inoue, T.; Watanabe, Y.; Yamaura, T.; Fukuhara, M.; Muto, S.; Okabe, N.; Matsumura, Y.; et al. Prognostic Impact of Hypoxia-Inducible miRNA-210 in Patients with Lung Adenocarcinoma. J. Oncol. 2015, 2015, 316745. [CrossRef] [PubMed]

87. Qu, Y.; Huang, W. Effects of microRNA-210 on the diagnosis and treatment of prostate cancer. Mol. Med. Rep. 2018, 18, 1740-1744. [CrossRef]

88. Grosso, S.; Doyen, J.; Parks, S.K.; Bertero, T.; Paye, A.; Cardinaud, B.; Gounon, P.; Lacas-Gervais, S.; Noël, A.; Pouysségur, J.; et al. MiR-210 promotes a hypoxic phenotype and increases radioresistance in human lung cancer cell lines. Cell Death Dis. 2013, 4, e544. [CrossRef]

89. Devlin, C.; Greco, S.; Martelli, F.; Ivan, M. miR-210: More than a silent player in hypoxia. IUBMB Life 2011, 63, 94-100. [CrossRef]

90. Sahraei, M.; Chaube, B.; Liu, Y.; Sun, J.; Kaplan, A.; Price, N.L.; Ding, W.; Oyaghire, S.; García-Milian, R.; Mehta, S.; et al. Suppressing miR-21 activity in tumor-associated macrophages promotes an antitumor immune response. J. Clin. Investig. 2019, 129, 5518-5536. [CrossRef]

91. Li, L.; Li, C.; Wang, S.; Wang, Z.; Jiang, J.; Wang, W.; Li, X.; Chen, J.; Liu, K.; Li, C.; et al. Exosomes Derived from Hypoxic Oral Squamous Cell Carcinoma Cells Deliver miR-21 to Normoxic Cells to Elicit a Prometastatic Phenotype. Cancer Res. 2016, 76, 1770-1780. [CrossRef]

92. Ullmann, P.; Nurmik, M.; Schmitz, M.; Rodriguez, F.; Weiler, J.; Qureshi-Baig, K.; Felten, P.; Nazarov, P.V.; Nicot, N.; Zuegel, N.; et al. Tumor suppressor miR-215 counteracts hypoxia-induced colon cancer stem cell activity. Cancer Lett. 2019, $450,32-41$. [CrossRef] [PubMed]

93. Bacci, L.; Aiello, A.; Ripoli, C.; Loria, R.; Pugliese, D.; Pierconti, F.; Rotili, D.; Strigari, L.; Pinto, F.; Bassi, P.F.; et al. H19-Dependent Transcriptional Regulation of $\beta 3$ and $\beta 4$ Integrins Upon Estrogen and Hypoxia Favors Metastatic Potential in Prostate Cancer. Int. J. Mol. Sci. 2019, 20, 4012. [CrossRef]

94. Wu, W.; Hu, Q.; Nie, E.; Yu, T.; Wu, Y.; Zhi, T.; Jiang, K.; Shen, F.; Wang, Y.; Zhang, J.; et al. Hypoxia induces H19 expression through direct and indirect Hif- $1 \alpha$ activity, promoting oncogenic effects in glioblastoma. Sci. Rep. 2017, 7, 45029. [CrossRef]

95. Matouk, I.J.; Mezan, S.; Mizrahi, A.; Ohana, P.; Abu-Lail, R.; Fellig, Y.; DeGroot, N.; Galun, E.; Hochberg, A. The oncofetal H19 RNA connection: Hypoxia, p53 and cancer. Biochim. Biophys. Acta BBA Bioenerg. 2010, 1803, 443-451. [CrossRef] [PubMed]

96. Liu, C.; Chen, Z.; Fang, J.; Xu, A.; Zhang, W.; Wang, Z. H19-derived miR-675 contributes to bladder cancer cell proliferation by regulating p53 activation. Tumor Biol. 2015, 37, 263-270. [CrossRef]

97. Zhang, L.; Song, X.; Wang, X.; Xie, Y.; Wang, Z.; Xu, Y.; You, X.; Liang, Z.; Cao, H. Circulating DNA of HOTAIR in serum is a novel biomarker for breast cancer. Breast Cancer Res. Treat. 2015, 152, 199-208. [CrossRef] [PubMed]

98. Zhang, S.; Chen, S.; Yang, G.; Gu, F.; Li, M.; Zhong, B.; Hu, J.; Hoffman, A.; Chen, M. Long Noncoding RNA HOTAIR as an Independent Prognostic Marker in Cancer: A Meta-Analysis. PLoS ONE 2014, 9, e105538. [CrossRef]

99. Zhou, C.; Ye, L.; Jiang, C.; Bai, J.; Chi, Y.; Zhang, H. Long noncoding RNA HOTAIR, a hypoxia-inducible factor- $1 \alpha$ activated driver of malignancy, enhances hypoxic cancer cell proliferation, migration, and invasion in non-small cell lung cancer. Tumor Biol. 2015, 36, 9179-9188. [CrossRef] [PubMed] 
100. Kogo, R.; Shimamura, T.; Mimori, K.; Kawahara, K.; Imoto, S.; Sudo, T.; Tanaka, F.; Shibata, K.; Suzuki, A.; Komune, S.; et al. Long Noncoding RNA HOTAIR Regulates Polycomb-Dependent Chromatin Modification and Is Associated with Poor Prognosis in Colorectal Cancers. Cancer Res. 2011, 71, 6320-6326. [CrossRef]

101. Xue, M.; Li, X.; Li, Z.; Chen, W. Urothelial carcinoma associated 1 is a hypoxia-inducible factor- $1 \alpha$-targeted long noncoding RNA that enhances hypoxic bladder cancer cell proliferation, migration, and invasion. Tumor Biol. 2014, 35, 6901-6912. [CrossRef] [PubMed]

102. Zhao, Z.-B.; Chen, F.; Bai, X.-F. Long Noncoding RNA MALAT1 Regulates Hepatocellular Carcinoma Growth Under Hypoxia via Sponging MicroRNA-200a. Yonsei Med. J. 2019, 60, 727-734. [CrossRef] [PubMed]

103. Hu, L.; Tang, J.; Huang, X.; Zhang, T.; Feng, X. Hypoxia exposure upregulates MALAT-1 and regulates the transcriptional activity of PTB-associated splicing factor in A549 lung adenocarcinoma cells. Oncol. Lett. 2018, 16, 294-300. [CrossRef]

104. Ikeda, S.; Kitadate, A.; Abe, F.; Takahashi, N.; Tagawa, H. Hypoxia-inducible KDM3A addiction in multiple myeloma. Blood Adv. 2018, 2, 323-334. [CrossRef] [PubMed]

105. Kong, X.; Zhao, Y.; Li, X.; Tao, Z.; Hou, M.; Ma, H. Overexpression of HIF-2a-Dependent NEAT1 Promotes the Progression of Non-Small Cell Lung Cancer through miR-1013p/SOX9/Wnt/ $\beta$-Catenin Signal Pathway. Cell. Physiol. Biochem. 2019, 52, 368-381. [CrossRef]

106. Huan, L.; Guo, T.; Wu, Y.; Xu, L.; Huang, S.; Xu, Y.; Liang, L.; He, X. Hypoxia induced LUCAT1/PTBP1 axis modulates cancer cell viability and chemotherapy response. Mol. Cancer 2020, 19, 11. [CrossRef]

107. Liu, Z.; Wang, Y.; Wang, L.; Yao, B.; Sun, L.; Liu, R.; Chen, T.; Niu, Y.; Tu, K.; Liu, Q. Long non-coding RNA AGAP2AS1, functioning as a competitive endogenous RNA, upregulates ANXA11 expression by sponging miR-16-5p and promotes proliferation and metastasis in hepatocellular carcinoma. J. Exp. Clin. Cancer Res. 2019, 38, 194. [CrossRef] [PubMed]

108. Wang, C.; Han, C.; Zhang, Y.; Liu, F. LncRNA PVT1 regulate expression of HIF1 $\alpha$ via functioning as ceRNA for miR-199a-5p in non-small cell lung cancer under hypoxia. Mol. Med. Rep. 2017, 17, 1105-1110. [CrossRef]

109. Wang, Y.; Chen, W.; Lian, J.; Zhang, H.; Yu, B.; Zhang, M.; Wei, F.; Wu, J.; Jiang, J.; Jia, Y.; et al. The lncRNA PVT1 regulates nasopharyngeal carcinoma cell proliferation via activating the KAT2A acetyltransferase and stabilizing HIF-1 $\alpha$. Cell Death Differ. 2020, 27, 695-710. [CrossRef]

110. Guo, X.; Lee, S.; Cao, P. The inhibitive effect of sh-HIF1A-AS2 on the proliferation, invasion, and pathological damage of breast cancer via targeting miR-548c-3p through regulating HIF-1 $\alpha$ /VEGF pathway in vitro and vivo. OncoTargets Ther. 2019, 12, 825-834. [CrossRef] [PubMed]

111. Ma, M.-Z.; Kong, X.; Weng, M.-Z.; Zhang, M.-D.; Qin, Y.-Y.; Gong, W.; Zhang, W.-J.; Quan, Z.-W. Long non-coding RNA-LET is a positive prognostic factor and exhibits tumor-suppressive activity in gallbladder cancer. Mol. Carcinog. 2015, 54, 1397-1406. [CrossRef]

112. Ferdin, J.; Nishida, N.; Wu, X.; Nicoloso, M.S.; Shah, M.Y.; Devlin, C.; Ling, H.; Shimizu, M.; Kumar, K.; Cortez, M.A.; et al. HINCUTs in cancer: Hypoxia-induced noncoding ultraconserved transcripts. Cell Death Differ. 2013, 20, 1675-1687. [CrossRef]

113. Takahashi, K.; Yan, I.K.; Haga, H.; Patel, T. Modulation of hypoxia-signaling pathways by extracellular linc-RoR. J. Cell Sci. 2014, 127, 1585-1594. [CrossRef] [PubMed]

114. Deng, S.-J.; Chen, H.-Y.; Ye, Z.; Zhu, S.; Zeng, Z.; He, C.; Liu, M.-L.; Huang, K.; Zhong, J.-X.; Xu, F.-Y.; et al. Hypoxia-induced LncRNA-BX111 promotes metastasis and progression of pancreatic cancer through regulating ZEB1 transcription. Oncogene 2018, 37, 5811-5828. [CrossRef] [PubMed]

115. Zhao, R.; Sun, F.; Bei, X.; Wang, X.; Zhu, Y.; Jiang, C.; Zhao, F.; Han, B.; Xia, S. Upregulation of the long non-coding RNA FALEC promotes proliferation and migration of prostate cancer cell lines and predicts prognosis of PCa patients. Prostate 2017, 77, 1107-1117. [CrossRef] [PubMed]

116. Li, X.; Deng, S.-J.; Zhu, S.; Jing-Yuan, C.; Cui, S.-P.; Chen, J.-Y.; Xiang, C.; Li, Q.-Y.; Heng-Yu, C.; Zhao, S.-F.; et al. Hypoxiainduced lncRNA-NUTF2P3-001 contributes to tumorigenesis of pancreatic cancer by derepressing the miR-3923/KRAS pathway. Oncotarget 2016, 7, 6000-6014. [CrossRef]

117. Lecerf, C.; Le Bourhis, X.; Adriaenssens, E. The long non-coding RNA H19: An active player with multiple facets to sustain the hallmarks of cancer. Cell. Mol. Life Sci. 2019, 76, 4673-4687. [CrossRef] [PubMed]

118. Corrado, C.; Costa, V.; Giavaresi, G.; Calabrese, A.; Conigliaro, A.; Alessandro, R. Long Non Coding RNA H19: A New Player in Hypoxia-Induced Multiple Myeloma Cell Dissemination. Int. J. Mol. Sci. 2019, 20, 801. [CrossRef]

119. Xue, M.; Chen, W.; Xiang, W.; Wang, R.; Chen, H.; Pan, J.; Pang, H.; Huilian, H.; Wang, X.; Hou, H.; et al. Hypoxic exosomes facilitate bladder tumor growth and development through transferring long non-coding RNA-UCA1. Mol. Cancer 2017, 16, 143. [CrossRef] [PubMed]

120. Choudhry, H.; Albukhari, A.; Morotti, M.; Haider, S.; Moralli, D.; Smythies, J.; Schödel, J.; Green, C.M.; Camps, C.; Buffa, F.; et al. Erratum: Tumor hypoxia induces nuclear paraspeckle formation through HIF-2 $\alpha$ dependent transcriptional activation of NEAT1 leading to cancer cell survival. Oncogene 2015, 34, 4546. [CrossRef] [PubMed]

121. Wang, W.; Yang, F.; Zhang, L.; Chen, J.; Zhao, Z.; Wang, H.; Wu, F.; Liang, T.; Yan, X.; Li, J.; et al. LncRNA profile study reveals four-lncRNA signature associated with the prognosis of patients with anaplastic gliomas. Oncotarget 2016, 7, 77225-77236. [CrossRef] [PubMed]

122. Qi, F.; Liu, X.; Wu, H.; Yu, X.; Wei, C.; Huang, X.; Ji, G.; Nie, F.; Wang, K. Long noncoding AGAP2-AS1 is activated by SP1 and promotes cell proliferation and invasion in gastric cancer. J. Hematol. Oncol. 2017, 10, 48. [CrossRef] [PubMed] 
123. Wu, X.; Ruan, L.; Yang, Y.; Mei, Q. Identification of crucial regulatory relationships between long non-coding RNAs and protein-coding genes in lung squamous cell carcinoma. Mol. Cell. Probes 2016, 30, 146-152. [CrossRef]

124. Gao, Y.-L.; Zhao, Z.-S.; Zhang, M.-Y.; Han, L.-J.; Dong, Y.-J.; Xu, B. Long Noncoding RNA PVT1 Facilitates Cervical Cancer Progression via Negative Regulating of miR-424. Oncol. Res. 2017, 25, 1391-1398. [CrossRef]

125. Puissegur, M.-P.; Mazure, N.M.; Bertero, T.; Pradelli, L.A.; Del Grosso, S.J.; Robbe-Sermesant, K.; Maurin, T.; Lebrigand, K.; Cardinaud, B.; Hofman, V.; et al. miR-210 is overexpressed in late stages of lung cancer and mediates mitochondrial alterations associated with modulation of HIF-1 activity. Cell Death Differ. 2010, 18, 465-478. [CrossRef]

126. Li, Y.; Zhang, D.; Wang, X.; Yao, X.; Ye, C.; Zhang, S.; Wang, H.; Chang, C.; Xia, H.; Wang, Y.-C.; et al. Hypoxia-inducible miR-182 enhances HIF1 $\alpha$ signaling via targeting PHD2 and FIH1 in prostate cancer. Sci. Rep. 2015, 5, 12495. [CrossRef] [PubMed]

127. Wang, X.-J.; Zhang, D.-L.; Fu, C.; Wei, B.-Z.; Li, G.-J. MiR-183 modulates multi-drug resistance in hepatocellular cancer (HCC) cells via miR-183-IDH2/SOCS6-HIF-1? feedback loop. Eur. Rev. Med. Pharmacol. Sci. 2016, 20, 2020-2027. [PubMed]

128. Gervin, E.; Shin, B.; Opperman, R.; Cullen, M.; Feser, R.; Maiti, S.; Majumder, M. Chemically Induced Hypoxia Enhances miRNA Functions in Breast Cancer. Cancers 2020, 12, 2008. [CrossRef]

129. Bandara, V.; Michael, M.Z.; Gleadle, J.M. Hypoxia represses microRNA biogenesis proteins in breast cancer cells. BMC Cancer 2014, 14, 533. [CrossRef]

130. Deng, B.; Du, J.; Hu, R.; Wang, A.-P.; Wu, W.-H.; Hu, C.-P.; Li, Y.-J.; Li, X.-H. MicroRNA-103/107 is involved in hypoxia-induced proliferation of pulmonary arterial smooth muscle cells by targeting HIF-1ß. Life Sci. 2016, 147, 117-124. [CrossRef]

131. Mandl, M.; Lieberum, M.-K.; Depping, R. A HIF-1 $\alpha$-driven feed-forward loop augments HIF signalling in Hep3B cells by upregulation of ARNT. Cell Death Dis. 2016, 7, e2284. [CrossRef] [PubMed]

132. Mandl, M.; Depping, R. Hypoxia-Inducible Aryl Hydrocarbon Receptor Nuclear Translocator (ARNT) (HIF-1 $\beta$ ): Is It a Rare Exception? Mol. Med. 2014, 20, 215-220. [CrossRef] [PubMed]

133. Wu, C.; Yang, T.; Liu, Y.; Lu, Y.; Yang, Y.; Liu, X.; Liu, X.; Ye, L.; Sun, Y.; Wang, X.; et al. ARNT/HIF-1ß links high-risk 1q21 gain and microenvironmental hypoxia to drug resistance and poor prognosis in multiple myeloma. Cancer Med. 2018, 7, 3899-3911. [CrossRef] [PubMed]

134. Xu, W.; Zhang, Z.; Zou, K.; Cheng, Y.; Yang, M.; Chen, H.; Wang, H.; Zhao, J.; Chen, P.; He, L.; et al. MiR-1 suppresses tumor cell proliferation in colorectal cancer by inhibition of Smad3-mediated tumor glycolysis. Cell Death Dis. 2017, 8, e2761. [CrossRef]

135. Lu, Y.; Ji, N.; Wei, W.; Sun, W.; Gong, X.; Wang, X. MiR-142 modulates human pancreatic cancer proliferation and invasion by targeting hypoxia-inducible factor 1 (HIF-1 $\alpha$ ) in the tumor microenvironments. Biol. Open 2017, 6, 252-259. [CrossRef]

136. Liu, L.; Wang, Y.; Bai, R.; Yang, K.; Tian, Z. MiR-186 inhibited aerobic glycolysis in gastric cancer via HIF-1 $\alpha$ regulation. Oncogenesis 2016, 5, e224. [CrossRef]

137. Yang, L.; Cao, M.; Zhang, J.; Li, X.; Sun, Q. LncRNA XIST modulates HIF-1A/AXL signaling pathway by inhibiting miR-93-5p in colorectal cancer. Mol. Genet. Genom. Med. 2020, 8, e1112. [CrossRef]

138. Sun, S.; Xia, C.; Xu, Y. HIF-1 $\alpha$ induced lncRNA LINC00511 accelerates the colorectal cancer proliferation through positive feedback loop. Biomed. Pharmacother. 2020, 125, 110014. [CrossRef]

139. Yang, B.; Jia, L.; Ren, H.; Jin, C.; Ren, Q.; Zhang, H.; Hu, D.; Zhang, H.; Hu, L.; Xie, T. LncRNA DLX6-AS1 increases the expression of HIF- $1 \alpha$ and promotes the malignant phenotypes of nasopharyngeal carcinoma cells via targeting MiR-199a-5p. Mol. Genet. Genom. Med. 2019, 8, e1017. [CrossRef] [PubMed]

140. Liu, Z.Z.; Tian, Y.F.; Wu, H.; Ouyang, S.Y.; Kuang, W.L. LncRNA H19 promotes glioma angiogenesis through miR-138/HIF$1 \alpha$ /VEGF axis. Neoplasma 2020, 67, 111-118. [CrossRef]

141. Wen, X.; Liu, X.; Mao, Y.-P.; Yang, X.-J.; Wang, Y.-Q.; Zhang, P.-P.; Lei, Y.; Hong, X.-H.; He, Q.-M.; Ma, J.; et al. Long non-coding RNA DANCR stabilizes HIF-1 $\alpha$ and promotes metastasis by interacting with NF90/NF45 complex in nasopharyngeal carcinoma Theranostics 2018, 8, 5676-5689. [CrossRef] [PubMed]

142. Liu, M.; Zhong, J.; Zeng, Z.; Huang, K.; Ye, Z.; Deng, S.; Chen, H.; Xu, F.; Li, Q.; Zhao, G. Hypoxia-induced feedback of HIF-1 $\alpha$ and lncRNA-CF129 contributes to pancreatic cancer progression through stabilization of p53 protein. Theranostics 2019, 9, 4795-4810. [CrossRef] [PubMed]

143. Wang, X.; Wang, Y.; Li, L.; Xue, X.; Xie, H.; Shi, H.; Hu, Y. A lncRNA coordinates with Ezh2 to inhibit HIF-1 $\alpha$ transcription and suppress cancer cell adaption to hypoxia. Oncogene 2020, 39, 1860-1874. [CrossRef] [PubMed]

144. Choi, Y.-J.; Kim, I.; Lee, J.E.; Park, J.-W. PIN1 transcript variant 2 acts as a long non-coding RNA that controls the HIF-1-driven hypoxic response. Sci. Rep. 2019, 9, 10599. [CrossRef] [PubMed] 